\title{
Photophysical Properties and Kinetic Studies of 2-Vinylpyridine-Based Cycloplatinated(II) Complexes Containing Various Phosphine Ligands ${ }^{\dagger}$
}

\author{
Vahideh Dolatyari ${ }^{1}$, Hamid R. Shahsavari ${ }^{1, *}$ (i), Sepideh Habibzadeh ${ }^{2}$, Reza Babadi Aghakhanpour ${ }^{1, *}$, \\ Sareh Paziresh ${ }^{1}$, Mohsen Golbon Haghighi ${ }^{3}$ and Mohammad Reza Halvagar ${ }^{4}$ \\ 1 Department of Chemistry, Institute for Advanced Studies in Basic Sciences (IASBS), Zanjan 45137-66731, Iran; \\ v.dolatyari@iasbs.ac.ir (V.D.); sareh.paziresh@gmail.com (S.P.) \\ 2 Department of Chemistry, Payame Noor University, Tehran P.O. BOX 19395-4697, Iran; spdh.hab@gmail.com \\ 3 Department of Chemistry, Shahid Beheshti University, Evin, Tehran 19839-69411, Iran; m_golbon@sbu.ac.ir \\ 4 Department of Inorganic Chemistry, Chemistry and Chemical Engineering Research Center of Iran, \\ Tehran 14968-13151, Iran; mhalvag@gmail.com \\ * Correspondence: shahsavari@iasbs.ac.ir (H.R.S.); babadi@iasbs.ac.ir (R.B.A.) \\ + Dedicated to Professor M. Teresa Moreno on the occasion of her 60th birthday.
}

check for updates

Citation: Dolatyari, V.; Shahsavari, H.R.; Habibzadeh, S.; Babadi Aghakhanpour, R.; Paziresh, S.; Golbon Haghighi, M.; Halvagar, M.R. Photophysical Properties and Kinetic Studies of 2-Vinylpyridine-Based Cycloplatinated(II) Complexes Containing Various Phosphine Ligands. Molecules 2021, 26, 2034 https://doi.org/10.3390/ molecules26072034

Academic Editors: Takashiro Akitsu and Stéphane Bellemin-Laponnaz

Received: 25 February 2021

Accepted: 30 March 2021

Published: 2 April 2021

Publisher's Note: MDPI stays neutral with regard to jurisdictional claims in published maps and institutional affiliations.

Copyright: (c) 2021 by the authors. Licensee MDPI, Basel, Switzerland. This article is an open access article distributed under the terms and conditions of the Creative Commons Attribution (CC BY) license (https:// creativecommons.org/licenses/by/ $4.0 /)$.
Abstract: A series of cycloplatinated(II) complexes with general formula of [PtMe $\left.(\mathrm{Vpy})\left(\mathrm{PR}_{3}\right)\right]$, Vpy = 2-vinylpyridine and $\mathrm{PR}_{3}=\mathrm{PPh}_{3}(\mathbf{1 a}) ; \mathrm{PPh}_{2} \mathrm{Me}(\mathbf{1 b}) ; \mathrm{PPhMe}_{2}(\mathbf{1 c})$, were synthesized and characterized by means of spectroscopic methods. These cycloplatinated(II) complexes were luminescent at room temperature in the yellow-orange region's structured bands. The $\mathrm{PPhMe}_{2}$ derivative was the strongest emissive among the complexes, and the complex with $\mathrm{PPh}_{3}$ was the weakest one. Similar to many luminescent cycloplatinated(II) complexes, the emission was mainly localized on the Vpy cyclometalated ligand as the main chromophoric moiety. The present cycloplatinated(II) complexes were oxidatively reacted with $\mathrm{MeI}$ to yield the corresponding cycloplatinated(IV) complexes. The kinetic studies of the reaction point out to an $\mathrm{S}_{\mathrm{N}} 2$ mechanism. The complex with $\mathrm{PPhMe}_{2}$ ligand exhibited the fastest oxidative addition reaction due to the most electron-rich $\mathrm{Pt}(\mathrm{II})$ center in its structure, whereas the $\mathrm{PPh}_{3}$ derivative showed the slowest one. Interestingly, for the $\mathrm{PPhMe}_{2}$ analog, the trans isomer was stable and could be isolated as both kinetic and thermodynamic product, while the other two underwent trans to cis isomerization.

Keywords: 2-vinylpyridine; cycloplatinated(II); photophysics; kinetic; phosphine

\section{Introduction}

Luminescent cyclometalated platinum(II) complexes have been significantly studied by many researchers in the last decades [1-11]; publications in this field of research are increasing [12-15]. The light-emitting devices [16-18] dye-sensitized solar cell [19], photoswitches [20,21], photocatalysts [22], and chemical or biochemical sensors [23] are various applications related to the luminescent cycloplatinated complexes. The cyclometalated ligand is the main chromophoric part in the creation of room-temperature phosphorescence. In addition, heavy metal like Pt induces high spin-orbit coupling and allows singlet-triplet intersystem crossing. In addition to the factors mentioned, the ancillary ligands play a very important role in such complexes' photophysical properties. These ligands control the electron density at the metal center and consequently the degree of Metal to Ligand Charge Transfer (MLCT) in the lowest energy transition. Some different arrangements for the ancillary ligands are expected depending on the charge (neutral or anionic) or binding mode (chelating and non-chelating) of the ancillary ligands, such as L^ X [24-26], L^L [6,27,28], L/X [2,29-32], L/L [33,34] and X/X [35,36].

Kinetic and mechanistic investigations of the oxidative addition reactions of organoplatinum(II) complexes have clearly proved that these reactions follow an $S_{\mathrm{N}} 2$ mechanism [37-45] 
with the exception of a few cases [46,47]. The $\mathrm{S}_{\mathrm{N}} 2$ mechanism with a large negative $\Delta S^{\neq}$ value can be observed for the small organic molecules, such as alkyl halides [48-51]. In these cases, theoretical approaches for mechanistic studies remarkably helped to certify the obtained experimental data [52-55]. The cycloplatinated(II) complexes with monophosphine ligands are the appropriate complexes for the study of the oxidative addition of alkyl halides on the Pt(II) center [56-62]. The phosphine ligands can affect electronically and sterically the rate constants and activation parameters. Electron-withdrawing or -donating properties of the substituents together with the Tolman cone angle significantly control the properties of monophosphine ligand [56]. In a comparison between $\mathrm{PPh}_{2} \mathrm{Me}$ and $\mathrm{PPh}_{3}$ ligands, the rate constants attributed to the $\mathrm{PPh}_{2} \mathrm{Me}$ derivative are 3-5-fold more than those for $\mathrm{PPh}_{3}$, indicating the electronic and steric differences [63]. In this manner, it is expected that the $\mathrm{PPhMe}_{2}$ derivative reactions should be considerably faster than those of $\mathrm{PPh}_{2} \mathrm{Me}$.

In the framework of our experiences on the photophysical [30,31,64-69] and the kinetico-mechanistic studies [70-74] of cyclometalated platinum complexes, some cycloplatinated(II or IV) complexes with 2-vinylpyridine (Vpy) and phosphine ligands ( $\mathrm{PPh}_{3}$ [75], $\mathrm{PPh}_{2} \mathrm{Me}$ [76] and $\mathrm{PPhMe}$ ) were designed. The kinetic and photophysical properties of the complex bearing $\mathrm{PPh}_{2} \mathrm{Me}$ were previously reported by us [76]. Therefore, herein, we added the $\mathrm{PPh}_{3}$ and $\mathrm{PPhMe}_{2}$ derivatives to make a meaningful trend and have a complete picture for comparison in terms of photophysical and kinetic studies. In addition, density functional theory (DFT) calculations were performed for both investigations and support the experimental data.

\section{Result and Discussion}

\subsection{Synthesis and Characterization}

All the synthetic steps are demonstrated in Scheme 1. In this scheme, the precursor cycloplatinated(II) complex [PtMe(Vpy)(DMSO)], A, [75-77] Vpy = 2-vinylpyridine, reacted with several monophosphines to give the complexes [PtMe(Vpy)(PR $)], \mathrm{PR}_{3}=\mathrm{PPh}_{3}$ (1a) [75]; $\mathrm{PPh}_{2} \mathrm{Me} \mathrm{(1b)} \mathrm{[76];} \mathrm{PPhMe}_{2}$ (1c). These complexes treated with MeI to give the corresponding cycloplatinated(IV) complexes of trans-[PtMe $\left.\mathrm{I}(\mathrm{Vpy})\left(\mathrm{PR}_{3}\right)\right], \mathrm{PR}_{3}=\mathrm{PPh}_{3}$ (2a); $\mathrm{PPh}_{2} \mathrm{Me}$ (2b) [76] $\mathrm{PPhMe}_{2}(\mathbf{2 c})$, and then cis-[PtMe $\left.\mathrm{I}_{2}(\mathrm{Vpy})\left(\mathrm{PR}_{3}\right)\right], \mathrm{PR}_{3}=\mathrm{PPh}_{3}(\mathbf{3 a})$; $\mathrm{PPh}_{2} \mathrm{Me}$ (3b) [76]; $\mathrm{PPhMe}_{2}$ (3c). We have previously reported $\mathbf{1} \mathbf{b}$ and its reaction with MeI (to form $\mathbf{2 b}$ and $\mathbf{3 b}$ ) kinetically investigated [76]. The $\mathrm{Pt}(\mathrm{IV})$ complex $\mathbf{2} \mathbf{b}$ was not stable and gradually converted to $\mathbf{3 b}$ isomer, and it was decomposed to the known $\mathrm{Pt}(\mathrm{II})$ complex and an organic compound [76]. The same interconversion happened for 1a with this difference that $\mathbf{2 a}$ (trans isomer) cannot be detected due to the very fast trans to cis isomerization. The cis isomer 3a is similarly decomposed and forms the same products (Scheme 2; trans[PtMeI $\left.\left(\mathrm{PPh}_{3}\right)_{2}\right], 4$, [ $\left.\left\{\mathrm{PtMe}_{2}(\mathrm{Vpy})\right\}_{2}(\mu-\mathrm{I})_{2}\right], 5$, and $\left.\mathrm{Z} / E-\left[\mathrm{C}_{8} \mathrm{H}_{9} \mathrm{~N}\right], 6\right)$ [76]. On the other hand, for $1 c$, the corresponding cycloplatinated(IV) $2 \mathrm{c}$ is stable and not converted to $3 \mathbf{c}$, and consequently, no decomposition process occurs (Scheme 2). The above-mentioned observations decisively point out the determining role of the phosphine ligand in determining the stability of the complexes.

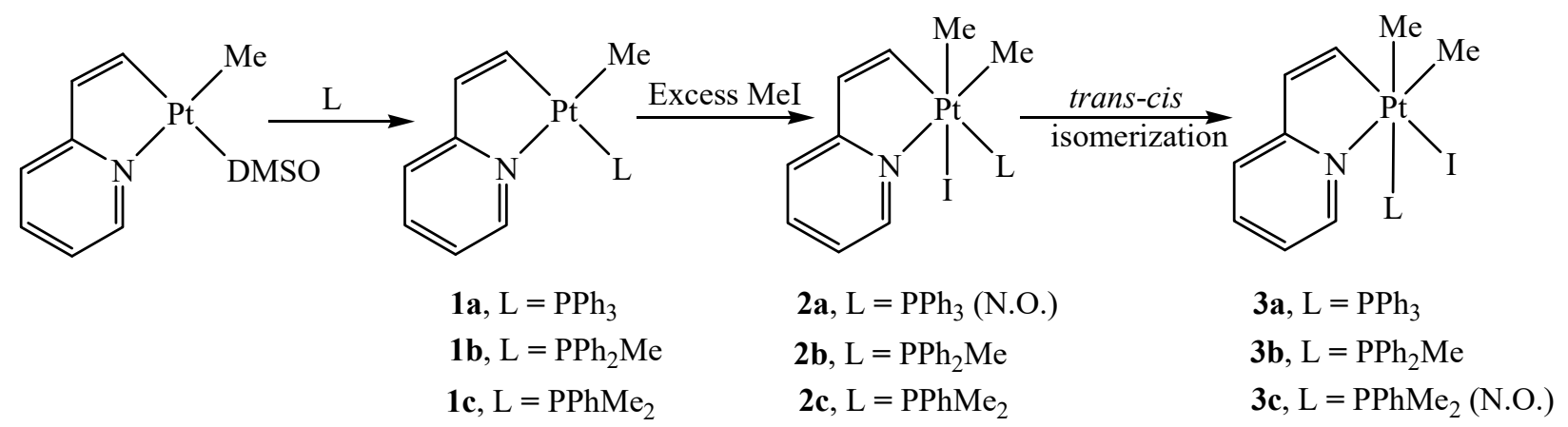

Scheme 1. Synthetic route for the complexes (DMSO = Dimethyl Sulfoxide; N.O. = not observed). 
<smiles>CC=Cc1ccccn1</smiles>

Scheme 2. Decomposition pathway of $\mathbf{3 a}$ (similar to that observed for $\mathbf{3 b}$ ) [76].

The formation of the new complexes $1 \mathrm{c}, 2 \mathrm{c}$ and $3 a$ confirmed by ${ }^{1} \mathrm{H}-$ and ${ }^{31} \mathrm{P}\left\{{ }^{1} \mathrm{H}\right\}-$ NMR spectroscopy and their spectra have all been shown in Figures S1-S8 from the Supplementary Material. The structures of $1 \mathrm{c}$ and $2 \mathrm{c}$ were further characterized by X-ray crystallography (Table S1 from the Supplementary Material), and their Oak Ridge Thermal Ellipsoid Plot (ORTEP) plots are shown in Figure 1, while their selected geometrical parameters are presented in its caption. The structure of $1 \mathrm{c}$ clearly confirms the proposed structure, and as expected, the C ligating atom of Vpy is located trans to the $\mathrm{P}$ of $\mathrm{PPhMe}_{2}$. The Vpy bite angle in 1c (N1-Pt1-C11) is $78.76^{\circ}$, which is very close to those observed for the other cyclometalated ligands in $\mathrm{Pt}(\mathrm{II})$ complexes [6]. Upon oxidative addition reaction, this angle in $2 \mathrm{c}$ does not show a meaningful change $\left(79.09^{\circ}\right)$. It can vividly be observed that the trans isomer is stable for $2 \mathrm{c}$ [72].
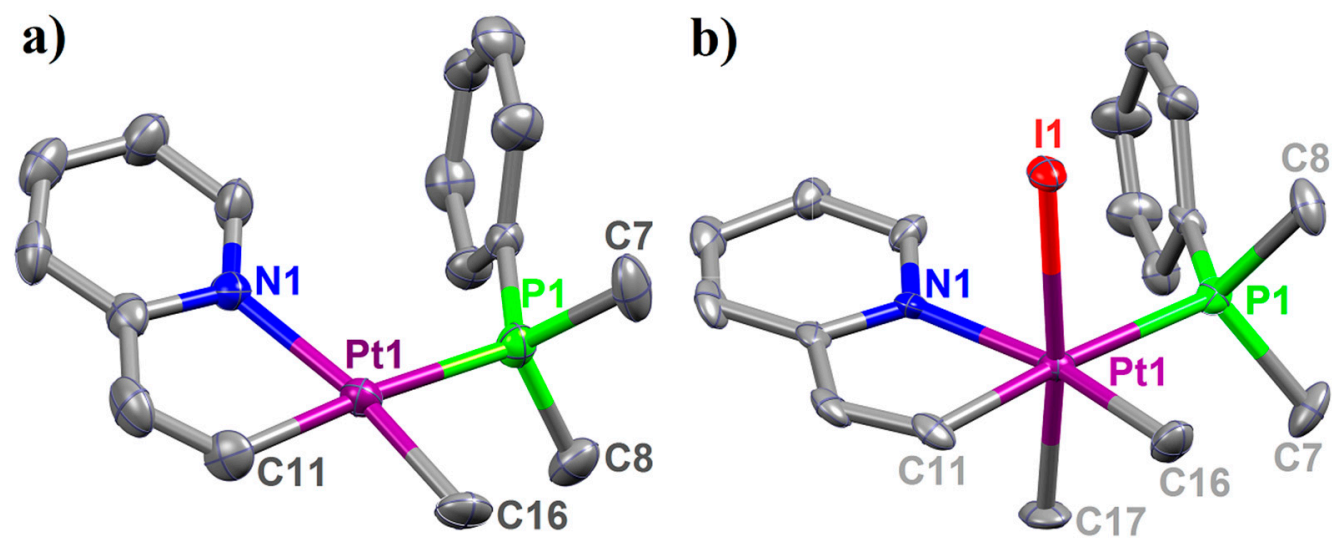

Figure 1. (a) ORTEP plot of the structure of 1c. Selected geometrical parameters ( $\left.\AA^{\circ}{ }^{\circ}\right)$ : Pt1-P1 2.306(2); Pt1-N1 2.141(6); Pt1-C11 2.013(8); Pt1-C16 2.077(7); C11-Pt1-N1 78.8(3); N1-Pt1-P1 104.34(18); P1-Pt1-C16 87.4(2); C16-Pt1-C11 89.6(4); C11-Pt1-P1 175.5(3); N1-Pt1-C16 168.2(3). (b) ORTEP plot of the structure of 2c. Selected geometrical parameters ( $\left.\AA^{\circ}\right)^{\circ}$ : Pt1-P1 2.395(6); Pt1-N1 2.142(19); Pt1-C11 1.98(2); Pt1-C16 2.01(3); Pt1-C17 2.19(2); Pt1-I1 2.7669(18); C11-Pt1-N1 79.1(9); N1-Pt1-P1 105.4(6); P1-Pt1-C16 84.2(8); C16-Pt1-C11 91.3(11); C11-Pt1-P1 175.4(7); N1-Pt1-C16 170.0(10); C17-Pt1-I1 175.4(7). Ellipsoids are drawn at the $50 \%$ probability level, and hydrogen atoms are omitted for clarity.

\subsection{Photophysical Properties}

The electronic transitions of the cycloplatinated(II) complexes 1a-c were initially investigated by the UV-vis spectroscopy, and their spectra were characterized in detail by the help of density functional theory (DFT) and time dependence-DFT (TD-DFT) calculations. In the first step, the ground states of all these three complexes were optimized with the consideration of $\mathrm{CH}_{2} \mathrm{Cl}_{2}$ as the solvent (the same solvent for experimental absorption spectra); the optimized structures are shown in Figure S9 from the Supplementary Material, and the selected geometrical parameters are listed in Table S2 from the Supplementary Material. Using the optimized structures in $\mathrm{CH}_{2} \mathrm{Cl}_{2}$, the frontier molecular orbitals (MO), including "HOMO to HOMO-5" (Highest Occupied Molecular Orbital) and "LUMO to LUMO+5," (Lowest Unoccupied Molecular Orbital) were obtained for all the complexes. 
The compositions of the selected molecular orbitals in terms of Pt and ligands are listed in Tables S3-S5 from the Supplementary Material, and the corresponding visual plots are depicted in Figures S10-S12 from the Supplementary Material. For all the cases, HOMO is predominantly localized on Pt and Vpy fragments, while in LUMO, Vpy is significantly dominated over the other fragments. In addition, the contribution of phosphine ligand is considerably increased in lower HOMOs and higher LUMOs.

As observed in Figure 2, although there is an acceptable agreement between the experimental UV-vis spectra and corresponding TD-DFT bars, an overestimation for the transition energies is observed in the visible region for all the cases. Table 1 indicates that the low-energy bands (the wavelengths used for yielding the emission bands) in all the complexes are attributed to the electronic transitions in the cyclometalated ligand and also charge transfer from Pt to the cyclometalated ligand (mixed ${ }^{1} \mathrm{ILCT} /{ }^{1} \mathrm{MLCT}$ (Intra Ligand Charge Transfer), $\mathrm{L}=\mathrm{Vpy}$ ). In other words, the first excited state (S1) is majorly related to the HOMO $\rightarrow$ LUMO transitions, which are assigned as ${ }^{1}$ MLCT $/{ }^{1}$ ILCT. However, in higher energy bands (higher excited states) and the ${ }^{1} \mathrm{ILCT}$ and ${ }^{1} \mathrm{MLCT},{ }^{1} \mathrm{ML} \mathrm{CT}^{\prime}\left(\mathrm{L}^{\prime}=\mathrm{PR}_{3}\right)$ and ${ }^{1} \mathrm{LL}$ 'CT (Ligand to Ligand Charge Transfer) electronic transitions are present, which involve the transitions with the phosphine ligand as the target.
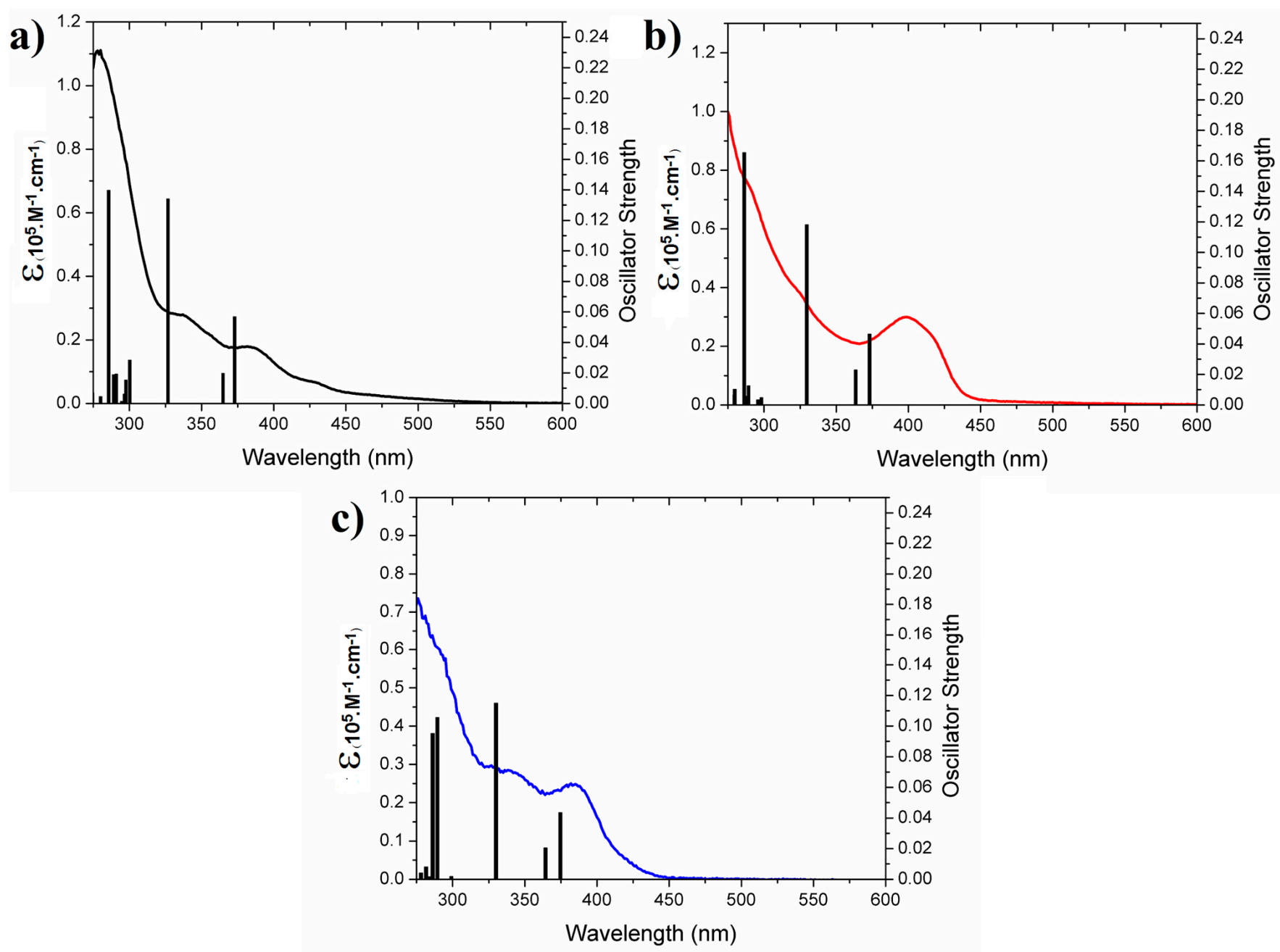

Figure 2. Overlaid experimental UV-vis spectra $\left(10^{-5} \mathrm{M}\right)$ and theoretical time-dependent density functional theory (TDDFT) bars for (a) 1a, (b) 1b, and (c) 1c. 
Table 1. Wavelengths and nature of transitions of $\mathbf{1 a}-\mathrm{c}\left(\mathrm{M}=\mathrm{Pt}, \mathrm{L}=\mathrm{Vpy}, \mathrm{L}^{\prime}=\mathrm{PR}_{3}\right)$.

\begin{tabular}{|c|c|c|c|c|c|}
\hline Complex & Excited State & $\begin{array}{l}\text { Oscillator } \\
\text { Strength }\end{array}$ & $\begin{array}{l}\text { Calculated } \lambda \\
(\mathrm{nm})\end{array}$ & $\begin{array}{c}\text { Transitions } \\
\text { (Major Contribution) }\end{array}$ & Assignment \\
\hline \multirow[t]{5}{*}{$1 \mathrm{a}$} & $\mathrm{S}_{0} \rightarrow \mathrm{S}_{1}$ & 0.0569 & 372.78 & $\mathrm{HOMO} \rightarrow$ LUMO $(89 \%)$ & ILCT/MLCT \\
\hline & $\mathrm{S}_{0} \rightarrow \mathrm{S}_{2}$ & 0.0197 & 364.76 & H-1 $\rightarrow$ LUMO (99\%) & MLCT \\
\hline & $\mathrm{S}_{0} \rightarrow \mathrm{S}_{3}$ & 0.1341 & 326.71 & H-2 $\rightarrow$ LUMO $(84 \%)$ & MLCT \\
\hline & $\mathbf{S}_{0} \rightarrow \mathbf{S}_{4}$ & 0.0285 & 300.17 & $\mathrm{HOMO} \rightarrow \mathrm{L}+1(93 \%)$ & $\mathrm{ML}^{\prime} \mathrm{CT} / \mathrm{LL}^{\prime} \mathrm{CT}$ \\
\hline & $\mathbf{S}_{0} \rightarrow \mathbf{S}_{10}$ & 0.1398 & 285.59 & $\mathrm{HOMO} \rightarrow \mathrm{L}+3(86 \%)$ & ILCT/ML'CT \\
\hline \multirow[t]{4}{*}{$1 b$} & $\mathbf{S}_{0} \rightarrow \mathbf{S}_{1}$ & 0.0465 & 373.00 & $\mathrm{HOMO} \rightarrow \mathrm{LUMO}(86 \%)$ & ILCT/MLCT \\
\hline & $\mathrm{S}_{0} \rightarrow \mathrm{S}_{2}$ & 0.0231 & 363.42 & $\mathrm{H}-1 \rightarrow \mathrm{LUMO}(95 \%)$ & MLCT \\
\hline & $\mathbf{S}_{0} \rightarrow \mathbf{S}_{3}$ & 0.1182 & 329.57 & H-2 $\rightarrow$ LUMO (85\%) & MLCT \\
\hline & $\mathbf{S}_{0} \rightarrow \mathbf{S}_{8}$ & 0.1654 & 286.30 & $\mathrm{HOMO} \rightarrow \mathrm{L}+2(80 \%)$ & ILCT/MLCT/ML'CT \\
\hline \multirow[t]{7}{*}{ 1c } & $\mathbf{S}_{0} \rightarrow \mathbf{S}_{1}$ & 0.0436 & 374.56 & $\mathrm{HOMO} \rightarrow$ LUMO $(90 \%)$ & ILCT/MLCT \\
\hline & $\mathbf{S}_{0} \rightarrow \mathbf{S}_{2}$ & 0.0206 & 364.26 & $\mathrm{H}-1 \rightarrow$ LUMO $(99 \%)$ & MLCT \\
\hline & $\mathbf{S}_{0} \rightarrow \mathbf{S}_{3}$ & 0.1151 & 330.04 & $\mathrm{H}-2 \rightarrow$ LUMO $(84 \%)$ & MLCT \\
\hline & $\mathbf{S}_{0} \rightarrow \mathbf{S}_{5}$ & 0.1056 & 289.38 & $\mathrm{HOMO} \rightarrow \mathrm{L}+1(76 \%)$ & ML'CT/LL'CT \\
\hline & $\mathrm{J}_{0} \rightarrow \mathrm{S}_{5}$ & 0.1000 & 289.00 & $\mathrm{HOMO} \rightarrow \mathrm{L}+2(18 \%)$ & ILCT/MLCT/ML'CT \\
\hline & & 0.0953 & 286.15 & $\mathrm{HOMO} \rightarrow \mathrm{L}+2(73 \%)$ & ILCT/MLCT/ML'CT \\
\hline & $\mathbf{S}_{0} \rightarrow \mathbf{S}_{6}$ & 0.0953 & 286.15 & $\mathrm{HOMO} \rightarrow \mathrm{L}+1(19 \%)$ & ML'CT/LL'CT \\
\hline
\end{tabular}

The photophysical properties of $\mathbf{1 a}-\mathbf{c}$ were examined using photoluminescence spectroscopy. All three complexes are luminescent in solid state at room temperature and low-temperature, having the bands in yellow-orange area (see Table 2 for the numerical emission parameters and Figure 3 for the emission spectra). Expectedly, the complexes exhibit brighter emissions at $77 \mathrm{~K}$ in relation to $298 \mathrm{~K}$, which is due to the more rigidity of the structures at low-temperature (see Table 2 for the quantum yield (QY) values). The lifetime values measured for the complexes at both temperature conditions are in microsecond scale, indicating phosphorescence character in the emissive states. The absolute QY values of the complexes obey the trend $\mathbf{1 c}>\mathbf{1 b}>\mathbf{1 a}$. This is probably related to the more electron-donating character of $\mathrm{PPhMe}_{2}$ compared to $\mathrm{PPh}_{2} \mathrm{Me}$ and $\mathrm{PPh}_{3}$, which makes the $\mathrm{Pt}(\mathrm{II})$ center and consequently the chromophoric ligand of Vpy to be more electron-rich. As can be seen in Figure 3, the emission spectra for the entire cases exhibit structured emission bands, which always point out that the emission is majorly localized on the cyclometalated ligands (large amount of ${ }^{3}$ ILCT in the emissive state together with the small amount of ${ }^{3}$ MLCT) $[6,30]$. The mixed ${ }^{3} \mathrm{ILCT} /{ }^{3} \mathrm{MLCT}$ character for the emission bands reflects the ${ }^{1}$ ILCT $/{ }^{1}$ MLCT character the in absorption spectra obtained by the TD-DFT calculations. The wavelength of emissions, being $550 \mathrm{~nm}$ at $298 \mathrm{~K}$ for all the complexes, is another evidence to confirm the identical emission nature in all the complexes (Vpy ligand). Upon lowering the temperature, a marginal blue shift is observed for the low-temperature bands in relation to their parents at room temperature, and also no tangible change is observed in the color or character of emissions. It should be noted that this blue shift is slightly larger for 1a compared to the other derivatives.

Table 2. Emission data for $1 \mathbf{a}-\mathbf{c}^{\text {a }}$.

\begin{tabular}{ccccc}
\hline Complex & State (Temp.) & $\lambda_{\text {em }} / \mathbf{n m}$ & $\tau / \mu \mathbf{s}$ & $\boldsymbol{\Phi}$ \\
\hline \multirow{2}{*}{$\mathbf{1 a}$} & Solid $(298 \mathrm{~K})$ & $550,581^{\max }$ & 0.9 & 0.01 \\
& Solid $(77 \mathrm{~K})$ & $530^{\max }, 575$ & 4.1 & 0.04 \\
\multirow{2}{*}{$\mathbf{1 b}$} & Solid $(298 \mathrm{~K})$ & $550,579^{\max }$ & 3.4 & 0.11 \\
& Solid $(77 \mathrm{~K})$ & $542^{\max }, 577$ & 7.1 & 0.27 \\
\multirow{2}{*}{$\mathbf{1 c}$} & Solid $(298 \mathrm{~K})$ & $550,585^{\max }$ & 5.3 & 0.17 \\
& Solid $(77 \mathrm{~K})$ & $543,585^{\max }$ & 15.5 & 0.44 \\
\hline
\end{tabular}

a The emissions were recorded upon excitation at $365 \mathrm{~nm}$; lifetime values were measured at the peak maxima. 

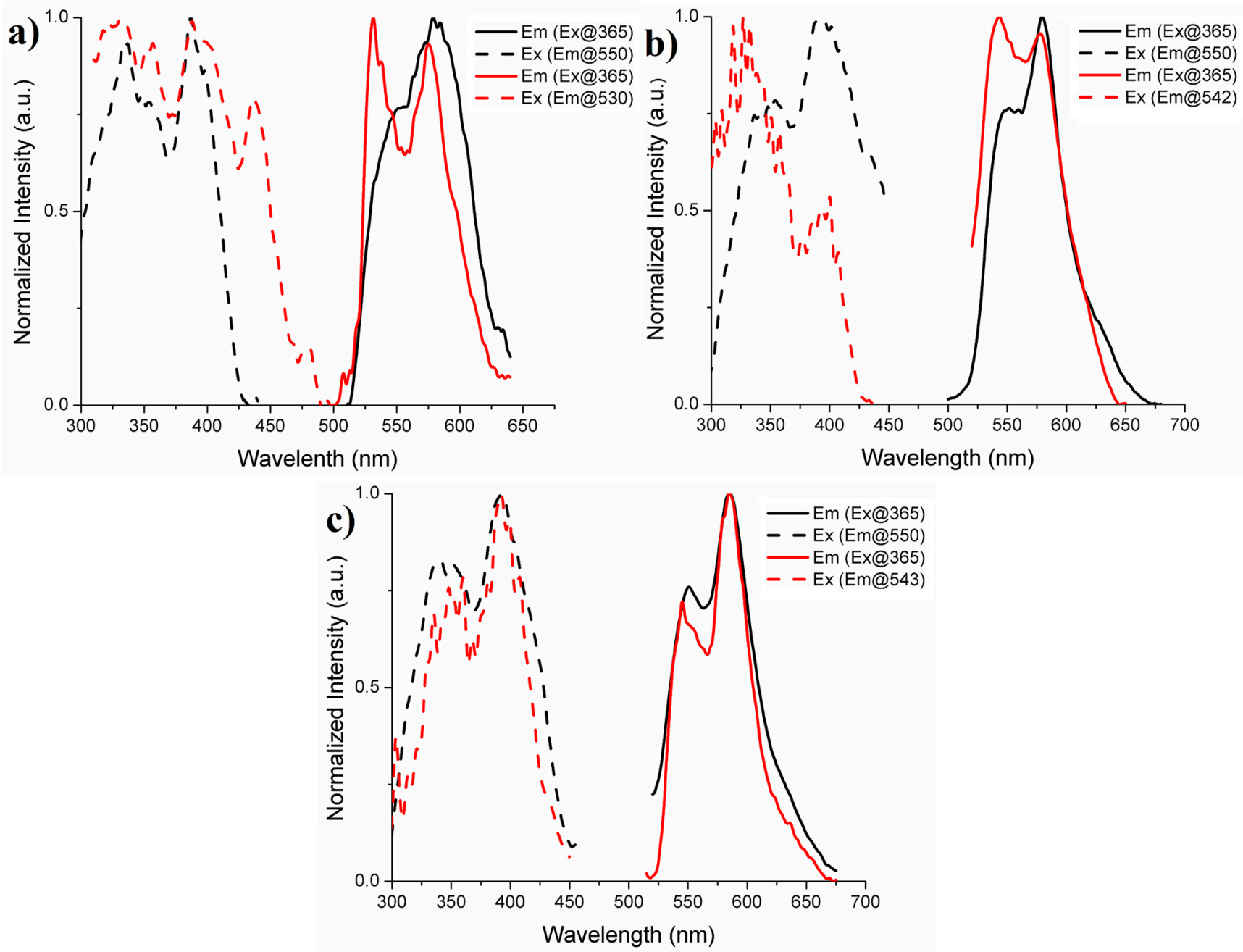

Figure 3. Emission (solid lines) and excitation (dashed lines) spectra of (a) 1a, (b) $\mathbf{1 b}$ and (c) 1c in solid state at $298 \mathrm{~K}$ (black) and $77 \mathrm{~K}$ (red).

\subsection{Kinetic Studies}

The oxidative addition of an excess amount of MeI on 1a and 1c in acetone solvent was kinetically studied by following the disappearance of the ${ }^{1}$ MLCT band of the cycloplatinated(II) complexes in the absorption spectra (see Figure 4 for the changes in the $\mathrm{UV}$-vis spectra of $\mathbf{1 a}$ and $\mathbf{1 c}$ at room temperature). The parameter $k_{\text {obs }}$ (pseudo-first-order rate constant) was calculated by the nonlinear least-squares fitting of the absorbance-time curves to a first-order equation. The $k_{\text {obs }} / \mathrm{MeI}$ concentration graphs were plotted for at least five temperatures (Figure 4), giving desirable straight-line plots with no intercept (no involvement of solvent or any dissociative pathway). The slope of the straight lines gives the second-order rate constant $\left(k_{2}\right)$. To calculate the activation parameters, the Eyring equation (Equation (1)) was employed at different temperatures (Figure 5). The large negative Entropy of Activation $\Delta S^{\#}$ values in Table 3 are normally indicative of second-order kinetics (first-order for $\mathrm{Pt}(\mathrm{II})$ complex and MeI) and $\mathrm{S}_{\mathrm{N}} 2$ mechanism. We have previously suggested an $\mathrm{S}_{\mathrm{N}} 2$ mechanism for $\mathbf{1 b}$, and the present reactions for $\mathbf{1 a}$ and $\mathbf{1 c}$ obey the previously reported mechanism. ${ }^{76}$ In this mechanism, the trans isomer is considered as the kinetic product, while the thermodynamic product is attributed to the cis isomer. At all the temperatures, the reaction of $\mathbf{1 c}$ (containing $\mathrm{PPhMe}_{2}$ ) with $\mathrm{MeI}$ is the fastest reaction, and $\mathbf{1 b}$ and $\mathbf{1 a}$ are the lower ranks, respectively. Therefore, the Enthalpy of Activation $\Delta H^{\#}$ value for the reaction of $\mathbf{1} \mathbf{c}$ with $\mathrm{MeI}$ is the lowest value (the lowest energy barrier). However, the $\Delta S^{\#}$ values are controlled by the steric hindrance induced by phosphine ligands. The highest $\Delta S^{\#}$ value is attributed to the $1 \mathrm{c}$ having $\mathrm{PPhMe}_{2}$ with the lowest steric 
hindrance. This is due to the associative mechanism with a penta-coordinated intermediate in which the lowest steric hindrance makes the highest $\Delta S^{\#}$ value.
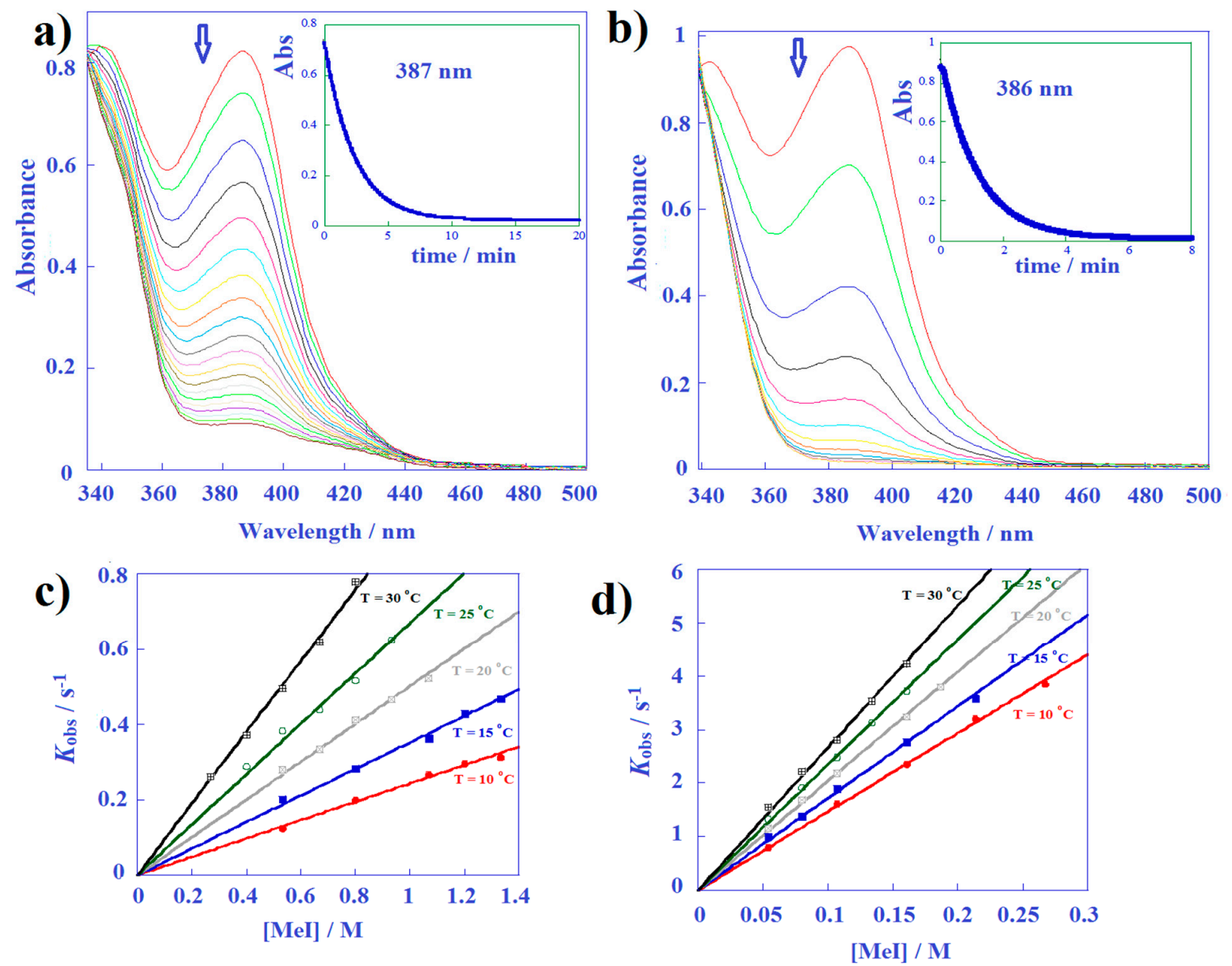

Figure 4. The changes in the UV-visible spectra of (a) 1a and (b) $1 \mathrm{c}$ with MeI in acetone at $25^{\circ} \mathrm{C}$ (inset is the variation of absorbance at a corresponding wavelength over time). Plots of the first-order rate constants $\left(k_{\mathrm{obs}} / \mathrm{s}^{-1}\right)$ for the reactions of (c) $1 \mathrm{a}$ and (d) 1c with MeI in acetone at different temperature conditions versus MeI concentration.

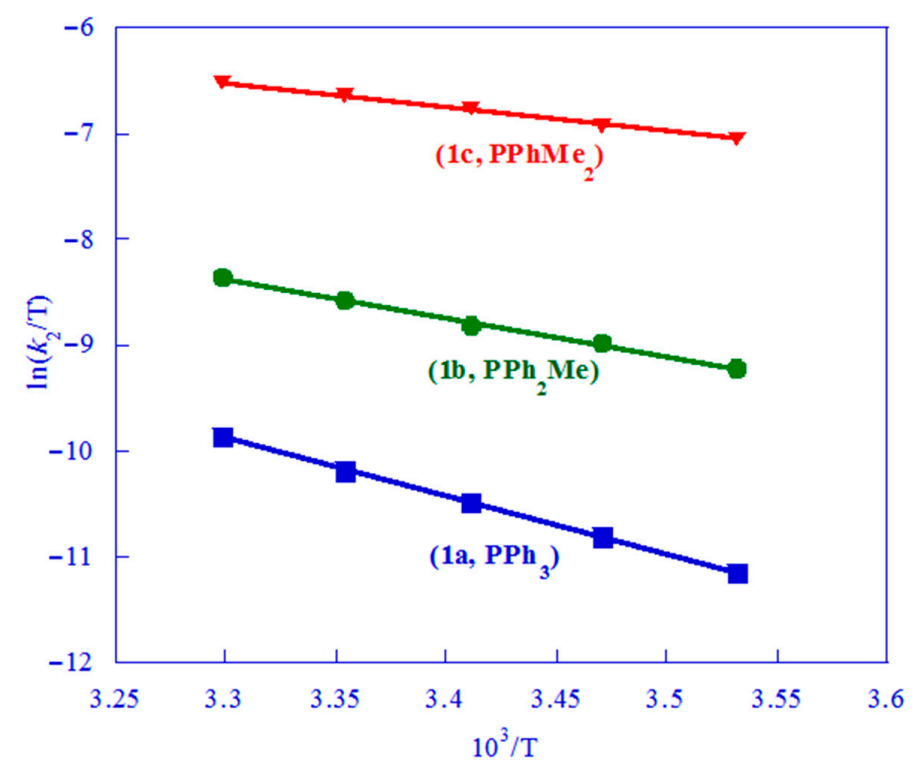

Figure 5. Eyring plots for the reactions of 1a, 1b [76] and 1c with MeI in acetone. 
Table 3. Second-order rate constants ${ }^{\mathrm{a}}$ and activation parameters ${ }^{\mathrm{b}}$ for the reaction of $\mathbf{1}$ with MeI in acetone ${ }^{\mathrm{c}}$.

\begin{tabular}{|c|c|c|c|c|c|c|c|c|}
\hline \multirow{2}{*}{ Complex } & \multirow{2}{*}{ L } & \multicolumn{5}{|c|}{$10^{2} k_{2} / \mathrm{L} \cdot \mathrm{mol}^{-1} \cdot \mathrm{s}^{-1}$ at Different Temperatures } & \multirow{2}{*}{$\Delta H^{\# /} \mathbf{k J} \cdot \mathrm{mol}^{-1}$} & \multirow{2}{*}{$\Delta S^{\# /} \mathbf{J} \cdot \mathbf{K}^{-1} \cdot \mathbf{m o l}^{-1}$} \\
\hline & & $10^{\circ} \mathrm{C}$ & $15^{\circ} \mathrm{C}$ & $20^{\circ} \mathrm{C}$ & $25^{\circ} \mathrm{C}$ & $30{ }^{\circ} \mathrm{C}$ & & \\
\hline $1 \mathrm{a}$ & $\mathrm{PPh}_{3}$ & 0.40 & 0.58 & 0.82 & 1.11 & 1.58 & $45.7 \pm 0.1$ & $-129 \pm 1$ \\
\hline $1 b^{c}$ & $\mathrm{PPh}_{2} \mathrm{Me}$ & 2.80 & 3.63 & 4.38 & 5.57 & 7.16 & $30.5 \pm 0.1$ & $-166 \pm 1$ \\
\hline 1c & $\mathrm{PPhMe}_{2}$ & 24.4 & 28.6 & 34.0 & 39.1 & 44.3 & $19.1 \pm 0.1$ & $-189 \pm 1$ \\
\hline
\end{tabular}

${ }^{\mathrm{a}}$ Estimated errors in $k_{2}$ values are $\pm 3 \%{ }^{\mathrm{b}}$ Activation parameters were calculated from the temperature dependence of the second-order rate constant in the usual way using the Eyring equation. ${ }^{\mathrm{c}}$ From ref [76].

From Figure 5 and Table 3, it can be understood that the rate of the reactions obeys the trend $\mathbf{1} \mathbf{c}\left(\mathrm{PPhMe}_{2}\right)>\mathbf{1} \mathbf{b}\left(\mathrm{PPh}_{2} \mathrm{Me}\right)>\mathbf{1 a}\left(\mathrm{PPh}_{3}\right)$. For example, at $25^{\circ} \mathrm{C}$, the rate for $\mathbf{1 b}$ is almost 5 times larger than that for $\mathbf{1 a}$, while the reaction of $\mathbf{1} \mathbf{c}$ is 7 times faster than that of $\mathbf{1 b}$. This is absolutely related to the electron-donating trend of the present monophosphine ligands $\left(\mathrm{PPhMe}_{2}>\mathrm{PPh}_{2} \mathrm{Me}>\mathrm{PPh}_{3}\right)$. The more electron-donating ability makes more electron-rich $\mathrm{Pt}$ (II) center, which is favorable for oxidative addition reaction and makes it to be faster. Therefore, in the formation of kinetic products, the electronic factors are effective. However, in trans to cis isomerization (kinetic product to thermodynamic product), the steric effects play a determining role. Additionally, the trans isomer can be stabilized by the electron-donating phosphine ligands like $\mathrm{PPhMe}_{2}$ [78] For the reaction of $\mathbf{1 a}$ with MeI, the kinetic product (2a) cannot be observed, and only the cis isomer (3a) as the thermodynamic product can be isolated. This trans to cis isomerization is attributed to a large steric hindrance and low electron-donating ability of the $\mathrm{PPh}_{3}$ ligand. In the case of the reaction of $\mathbf{1 b}$ with $\mathrm{MeI}[76]$ having a phosphine $\left(\mathrm{PPh}_{2} \mathrm{Me}\right)$ with less steric hindrance and more electron-donating ability compared with $\mathrm{PPh}_{3}$, the trans isomer can be isolated and even completely characterized, but it will gradually be converted to the cis product and eventually decomposed [74]. However, if $\mathrm{PPh}_{2} \mathrm{Me}$ is replaced by $\mathrm{PPhMe}_{2}$, due to the smaller steric hindrance and large electron-donating ability imposed by $\mathrm{PPhMe}_{2}$, the trans to cis isomerization is practically prohibited and trans isomer $\mathbf{2 c}$ as the kinetic product is completely stable so that it can be crystallized and characterized by X-ray crystallography.

\section{Experimental}

\subsection{General Procedures and Materials}

${ }^{1} \mathrm{H}-\mathrm{NMR}(400 \mathrm{MHz})$ and ${ }^{31} \mathrm{P}\left\{{ }^{1} \mathrm{H}\right\}-\mathrm{NMR}(162 \mathrm{MHz})$ spectra were recorded on a Bruker Avance III instrument (Ettlingen, Germany) and are referenced to the external standards, i.e., $\mathrm{SiMe}_{4}$ and $85 \% \mathrm{H}_{3} \mathrm{PO}_{4}$, respectively. The chemical shifts ( $\delta$ ) being reported as ppm and coupling constants $(J)$ expressed in Hz. UV-vis absorption spectra and kinetic studies were carried out by using an Ultrospec 4000 Pro, UV-vis spectrometer (Little Chalfont, UK) with temperature control using a Pharmacia Biotech constant-temperature bath. Excitation and emission spectra were obtained on a PerkinElmer LS45 fluorescence spectrometer (Beaconsfield, UK) with the lifetimes measured in phosphorimeter mode, and the quantum yields of the complexes were measured using an integrating sphere. 2-Vinylpyridine (Vpy), triphenylphosphine $\left(\mathrm{PPh}_{3}\right)$, dimethylphenylphosphine $\left(\mathrm{PPhMe}_{2}\right)$ and the other chemicals were purchased from Sigma Aldrich (St. Louis, MO, USA). All of the reactions were carried out under an argon atmosphere, and all of the common solvents were purified and dried according to standard procedures. The complexes [PtMe(Vpy)(DMSO)], $\mathbf{A}$, [PtMe(Vpy) $\left.\left(\mathrm{PPh}_{3}\right)\right], \mathbf{1 a},\left[\mathrm{PtMe}(\mathrm{Vpy})\left(\mathrm{PPh}_{2} \mathrm{Me}\right)\right], \mathbf{1 b}$, and $\left[\mathrm{PtMe}_{2} \mathrm{I}(\mathrm{Vpy})\left(\mathrm{PPh}_{2} \mathrm{Me}\right)\right]$, 2b, were prepared according to literature methods [75-77]. The NMR labeling for the Vpy ligand for clarifying the chemical shift assignments is shown in Scheme 3. New NMR data for 1a, ${ }^{1} \mathrm{H}-\mathrm{NMR}\left(400 \mathrm{MHz}\right.$, acetone- $\left.d_{6}, 295 \mathrm{~K}\right): \delta 0.69\left(\mathrm{~d},{ }^{3} J_{\mathrm{PH}}=8.1,{ }^{2} J_{\mathrm{PtH}}=84.2 \mathrm{~Hz}, 3 \mathrm{H}, \mathrm{PtMe}\right)$, $6.57\left(\mathrm{t},{ }^{3} J_{\mathrm{HH}}=6.3 \mathrm{~Hz}, 1 \mathrm{H}, \mathrm{H}^{5}\right), 7.25\left(\mathrm{~d},{ }^{3} J_{\mathrm{HH}}=7.8 \mathrm{~Hz}, 1 \mathrm{H}, \mathrm{H}^{3}\right), 7.33\left(\mathrm{dd},{ }^{3} J_{\mathrm{HH}}=9.2 \mathrm{~Hz}\right.$, $\left.{ }^{4} J_{\mathrm{PH}}=15.2 \mathrm{~Hz},{ }^{3} \mathrm{~J}_{\mathrm{PtH}}=94.3 \mathrm{~Hz}, 1 \mathrm{H}, \mathrm{H}^{\alpha}\right), 7.44-7.49\left(\mathrm{~m}, 9 \mathrm{H}, \mathrm{H}^{m}\right.$ and $\left.\mathrm{H}^{p} \mathrm{PPh}_{3}\right), 7.58(\mathrm{~d}$, $\left.{ }^{3} J_{\mathrm{HH}}=5.3 \mathrm{~Hz},{ }^{3} J_{\mathrm{PtH}}=16.4 \mathrm{~Hz}, 1 \mathrm{H}, \mathrm{H}^{6}\right), 7.68-7.74\left(\mathrm{~m}, 7 \mathrm{H}, \mathrm{H}^{4}\right.$ and $\left.\mathrm{H}^{o} \mathrm{PPh}_{3}\right), 7.76(\mathrm{dd}$, 
$\left.{ }^{3} J_{\mathrm{HH}}=9.2 \mathrm{~Hz},{ }^{3} J_{\mathrm{PH}}=7.8 \mathrm{~Hz},{ }^{2} J_{\mathrm{PtH}}=163.4 \mathrm{~Hz}, 1 \mathrm{H}, \mathrm{H}^{\beta}\right) ;{ }^{31} \mathrm{P}\left\{{ }^{1} \mathrm{H}\right\}-\mathrm{NMR}(162 \mathrm{MHz}$, acetone$\left.d_{6}, 295 \mathrm{~K}\right): \delta 31.8\left(\mathrm{~s},{ }^{1} J_{\mathrm{PtP}}=2021 \mathrm{~Hz}, 1 \mathrm{P}\right)$.<smiles>c1ccn2c(c1)c1ccccn12</smiles>

Scheme 3. NMR labeling for the protons of Vpy moiety $\left(\alpha=\mathrm{H}^{\alpha} ; \beta=\mathrm{H}^{\beta}\right)$.

\subsection{Synthesis of Complexes}

\subsection{1. [PtMe(Vpy) $\left.\left(\mathrm{PPhMe}_{2}\right)\right], 1 \mathrm{c}$}

To a solution of $[\mathrm{PtMe}(\mathrm{Vpy})(\mathrm{DMSO})], \mathbf{A},(150 \mathrm{mg}, 0.382 \mathrm{mmol})$ in acetone $(15 \mathrm{~mL})$ was added $\mathrm{PPhMe}_{2}$ ligand $(60 \mu \mathrm{L}, 0.420 \mathrm{mmol}, 1.1$ equivalent). The mixture was stirred at room temperature for $2 \mathrm{~h}$. The deep orange solution was concentrated to a small volume $(\sim 2 \mathrm{~mL})$, and $n$-hexane was added $(3 \mathrm{~mL})$ to give an orange solid identified as 1c. Yield: 93\%; Anal. Calcd for $\mathrm{C}_{16} \mathrm{H}_{20} \mathrm{NPPt}$ (452.39); C, 42.48; $\mathrm{H}, 4.46 ; \mathrm{N}, 3.10$. Found: C, 42.91; H, 4.56; N, 3.17. ${ }^{1} \mathrm{H}-\mathrm{NMR}\left(400 \mathrm{MHz}\right.$, acetone- $\left.d_{6}, 295 \mathrm{~K}\right): \delta 0.95(\mathrm{~d}$, $\left.{ }^{3} J_{\mathrm{PH}}=8.7,{ }^{2} J_{\mathrm{PtH}}=85.3 \mathrm{~Hz}, 3 \mathrm{H}, \mathrm{PtMe}\right), 1.71\left(\mathrm{~d},{ }^{2} J_{\mathrm{PH}}=7.7,{ }^{3} J_{\mathrm{PtH}}=20.9 \mathrm{~Hz}, 6 \mathrm{H}, \mathrm{Me}\right.$ of $\left.\mathrm{PPhMe}_{2}\right), 6.77\left(\mathrm{td},{ }^{3} J_{\mathrm{HH}}=6.5 \mathrm{~Hz},{ }^{4} J_{\mathrm{HH}}=1.4 \mathrm{~Hz}, 1 \mathrm{H}, \mathrm{H}^{5}\right), 7.20\left(\mathrm{~d},{ }^{3} J_{\mathrm{HH}}=7.9 \mathrm{~Hz}, 1 \mathrm{H}, \mathrm{H}^{3}\right)$, $7.24\left(\mathrm{dd},{ }^{3} J_{\mathrm{HH}}=9.4 \mathrm{~Hz},{ }^{4} J_{\mathrm{PH}}=15.7 \mathrm{~Hz},{ }^{3} J_{\mathrm{PtH}}=87.1 \mathrm{~Hz}, 1 \mathrm{H}, \mathrm{H}^{\alpha}\right), 7.45-7.48\left(\mathrm{~m}, 3 \mathrm{H}, \mathrm{H}^{4}\right.$ and $\left.\mathrm{H}^{m} \mathrm{PPhMe}_{2}\right), 7.72\left(\mathrm{t},{ }^{3} \mathrm{JHH}_{\mathrm{HH}}=8.2 \mathrm{~Hz}, 1 \mathrm{H}, \mathrm{H}^{p} \mathrm{PPhMe}_{2}\right), 7.73\left(\mathrm{t},{ }^{3} \mathrm{~J}_{\mathrm{HH}}+{ }^{3} J_{\mathrm{PH}}=9.1 \mathrm{~Hz}, 7.8 \mathrm{~Hz}\right.$, $\left.{ }^{2} J_{\mathrm{PtH}}=149.1 \mathrm{~Hz}, 1 \mathrm{H}, \mathrm{H}^{\beta}\right), 7.89-7.95\left(\mathrm{~m}, 3 \mathrm{H}, \mathrm{H}^{6}\right.$ and $\left.\mathrm{H}^{o} \mathrm{PPh}_{3}\right) ;{ }^{31} \mathrm{P}\left\{{ }^{1} \mathrm{H}\right\}-\mathrm{NMR}(162 \mathrm{MHz}$, acetone- $\left.d_{6}, 295 \mathrm{~K}\right): \delta-4.6\left(\mathrm{~s},{ }^{1} J_{\mathrm{PtP}}=1967 \mathrm{~Hz}, 1 \mathrm{P}\right)$.

\subsection{2. cis-[PtMe $\left.2 \mathrm{I}(\mathrm{Vpy})\left(\mathrm{PPh}_{3}\right)\right]$, 3a}

To solution of $\left[\mathrm{PtMe}(\mathrm{Vpy})\left(\mathrm{PPh}_{3}\right)\right], \mathbf{1 a},(100 \mathrm{mg}, 0.173 \mathrm{mmol})$ in acetone $(15 \mathrm{~mL})$ were added $250 \mu \mathrm{L}$ (excess, 25-fold) of MeI. The solution was stirred for $3 \mathrm{~h}$ at room temperature, then diethyl ether was added to give a precipitate, which was filtered, washed with diethyl ether to give the product as a pale yellow solid identified as $\mathbf{3 a}$. The product was dried in vacuum. Yield: 79\%; Anal. Calcd for $\mathrm{C}_{27} \mathrm{H}_{27} \mathrm{INPPt}$ (718.47); $\mathrm{C}, 45.14 ; \mathrm{H}, 3.79 ; \mathrm{N}, 1.95$. Found: C, 45.32; H, 3.87; N, 1.82. ${ }^{1} \mathrm{H}-\mathrm{NMR}\left(400 \mathrm{MHz}\right.$, acetone- $\left.d_{6}, 295 \mathrm{~K}\right): 1.04\left(\mathrm{~d},{ }^{3} \mathrm{~J}_{\mathrm{PH}}=7.8\right.$, ${ }^{2} J_{\mathrm{PtH}}=60.7 \mathrm{~Hz}, 3 \mathrm{H}$, Me ligand trans to $\left.\mathrm{PPh}_{3}, \mathrm{PtMe}\right), 1.75\left(\mathrm{~d},{ }^{3} J_{\mathrm{PH}}=7.9,{ }^{2} J_{\mathrm{PtH}}=69.8 \mathrm{~Hz}, 3 \mathrm{H}\right.$, Me ligand trans to $\mathrm{N}$ of Vpy, PtMe), $6.65\left(\mathrm{dd},{ }^{3} \mathrm{~J}_{\mathrm{HH}}=6.9 \mathrm{~Hz},{ }^{4} J_{\mathrm{PH}}=2.6 \mathrm{~Hz},{ }^{3} J_{\mathrm{PtH}}=104.2 \mathrm{~Hz}\right.$, $\left.1 \mathrm{H}, \mathrm{H}^{\alpha}\right), 6.95\left(\mathrm{t}^{3}{ }^{3} \mathrm{HH}_{\mathrm{H}}=6.7 \mathrm{~Hz}, 1 \mathrm{H}, \mathrm{H}^{5}\right), 7.31-7.45\left(\mathrm{~m}, 9 \mathrm{H}, \mathrm{H}^{m}\right.$ and $\left.\mathrm{H}^{p} \mathrm{PPh}_{3}\right), 7.51-7.96(\mathrm{~m}$, $9 \mathrm{H}, \mathrm{H}^{\beta}, \mathrm{H}^{3}, \mathrm{H}^{4}$ and $\left.\mathrm{H}^{o} \mathrm{PPh}_{3}\right), 9.07\left(\mathrm{~d},{ }^{3} J_{\mathrm{HH}}=5.1 \mathrm{~Hz},{ }^{3} J_{\mathrm{PtH}}=13.3 \mathrm{~Hz}, 1 \mathrm{H}, \mathrm{H}^{6}\right) ;{ }^{31} \mathrm{P}\left\{{ }^{1} \mathrm{H}\right\}-\mathrm{NMR}$ $\left(162 \mathrm{MHz}\right.$, acetone- $\left.d_{6}, 295 \mathrm{~K}\right): \delta-7.8\left(\mathrm{~s},{ }^{1} J_{\mathrm{PtP}}=1036 \mathrm{~Hz}, 1 \mathrm{P}\right)$.

\subsection{3. trans- $\left[\mathrm{PtMe}_{2} \mathrm{I}(\mathrm{Vpy})\left(\mathrm{PPhMe}_{2}\right)\right], 2 \mathrm{c}$}

To solution of [PtMe(Vpy)(PPhMe $)]$, 1c, $(100 \mathrm{mg}, 0.221 \mathrm{mmol})$ in acetone $(15 \mathrm{~mL})$ were added $150 \mu \mathrm{L}$ (excess, 10-fold) of MeI. The solution was stirred for $3 \mathrm{~h}$ at room temperature, then diethyl ether was added to give a precipitate, which was filtered, washed with diethyl ether to give the product as a pale yellow solid identified as 2c. The product was dried in vacuum. Yield: $81 \%$; Anal. Calcd for $\mathrm{C}_{17} \mathrm{H}_{23} \mathrm{INPPt}$ (594.33); C, 34.36; H, 3.90; N, 2.36. Found: C, 34.25; H, 3.92; N, 2.33. ${ }^{1} \mathrm{H}-\mathrm{NMR}(400 \mathrm{MHz}$, acetone- $\left.d_{6}, 295 \mathrm{~K}\right): 0.65\left(\mathrm{~d},{ }^{3} J_{\mathrm{PH}}=7.6,{ }^{2} J_{\mathrm{PtH}}=70.3 \mathrm{~Hz}, 3 \mathrm{H}\right.$, Me ligand trans to I, PtMe), $1.26\left(\mathrm{~d},{ }^{3} J_{\mathrm{PH}}=8.2,{ }^{2} \mathrm{~J}_{\mathrm{PtH}}=69.4 \mathrm{~Hz}, 3 \mathrm{H}, \mathrm{Me}\right.$ ligand trans to $\mathrm{N}$ of $\left.\mathrm{Vpy}, \mathrm{PtMe}\right), 1.98(\mathrm{~d}$, ${ }^{2} J_{\mathrm{PH}}=8.9,{ }^{3} J_{\mathrm{PtH}}=12.6 \mathrm{~Hz}, 3 \mathrm{H}, \mathrm{Me}$ of $\left.\mathrm{PPhMe}_{2}\right), 2.21\left(\mathrm{~d},{ }^{2} J_{\mathrm{PH}}=9.0,{ }^{3} J_{\mathrm{PtH}}=11.1 \mathrm{~Hz}, 3 \mathrm{H}\right.$, Me of $\left.\mathrm{PPhMe}_{2}\right), 6.83\left(\mathrm{td},{ }^{3} J_{\mathrm{HH}}=6.6 \mathrm{~Hz},{ }^{4} J_{\mathrm{HH}}=1.3 \mathrm{~Hz}, 1 \mathrm{H}, \mathrm{H}^{5}\right), 7.03\left(\mathrm{dd},{ }^{3} J_{\mathrm{HH}}=8.0 \mathrm{~Hz}\right.$, $\left.{ }^{4} J_{\mathrm{PH}}=21.7 \mathrm{~Hz},{ }^{3} J_{\mathrm{PtH}}=66.9 \mathrm{~Hz}, 1 \mathrm{H}, \mathrm{H}^{\alpha}\right), 7.44\left(\mathrm{~d},{ }^{3} J_{\mathrm{HH}}=7.8 \mathrm{~Hz}, 1 \mathrm{H}, \mathrm{H}^{3}\right), 7.52-7.59(\mathrm{~m}, 3 \mathrm{H}$, $\mathrm{H}^{p}$ and $\left.\mathrm{H}^{m} \mathrm{PPhMe}_{2}\right), 7.72\left(\mathrm{td},{ }^{3} J_{\mathrm{HH}}=7.7 \mathrm{~Hz},{ }^{4} J_{\mathrm{HH}}=1.5 \mathrm{~Hz}, 1 \mathrm{H}, \mathrm{H}^{4}\right), 7.81\left(\mathrm{~d},{ }^{3} J_{\mathrm{HH}}=5.1 \mathrm{~Hz}\right.$, 
$\left.{ }^{3} J_{\mathrm{PtH}}=12.0 \mathrm{~Hz}, 1 \mathrm{H}, \mathrm{H}^{6}\right), 7.86-7.92\left(\mathrm{~m}, 2 \mathrm{H}, \mathrm{H}^{o} \mathrm{PPh}_{3}\right), 8.03\left(\mathrm{dd},{ }^{3} J_{\mathrm{HH}}=8.0 \mathrm{~Hz},{ }^{3} J_{\mathrm{PH}}=9.2 \mathrm{~Hz}\right.$,

$\left.{ }^{2} J_{\mathrm{PtH}}=75.6 \mathrm{~Hz}, 1 \mathrm{H}, \mathrm{H}^{\beta}\right) ;{ }^{31} \mathrm{P}\left\{{ }^{1} \mathrm{H}\right\}-\mathrm{NMR}\left(162 \mathrm{MHz}\right.$, acetone-d $\left.d_{6}, 295 \mathrm{~K}\right): \delta-37.8(\mathrm{~s}$,

$\left.{ }^{1} J_{\mathrm{PtP}}=1278 \mathrm{~Hz}, 1 \mathrm{P}\right)$.

\subsection{Kinetic Study}

A solution of $1 \mathbf{a}$ or $1 \mathrm{c}$ in acetone $\left(3 \mathrm{~mL}, 2.5 \times 10^{-4} \mathrm{M}\right)$ in a cuvette was thermostated at $25{ }^{\circ} \mathrm{C}$, and a known excess of MeI $(150 \mu \mathrm{L}$, 3200-fold for 1a; $15 \mu \mathrm{L}, 320$-fold for 1c) was added using a microsyringe. After rapid stirring, the absorbance at $\lambda=387$ (1a) or 386 (1c) nm was collected with time. The absorbance-time curves were analyzed by the pseudo-first-order method $\left(\mathrm{A}_{\mathrm{t}}=\left(\mathrm{A}_{0}-\mathrm{A}_{\infty}\right) \exp \left(-k_{\mathrm{obs}} \mathrm{t}\right)+\mathrm{A}_{\infty}\right)$. The same method was used at other concentrations, and temperatures $\left(10,15,25\right.$, and $\left.30^{\circ} \mathrm{C}\right)$ and activation parameters $\left(\Delta \mathrm{S}^{\#}\right.$ and $\left.\Delta \mathrm{H}^{\#}\right)$ were obtained from the Eyring equation (Equation (1)) and the full data are collected in Table 1. Ref. [79]

$$
\ln \left(\frac{k_{2}}{\mathrm{~T}}\right)=\ln \left(\frac{k_{\mathrm{B}}}{h}\right)+\frac{\Delta \mathrm{S}^{\ddagger}}{\mathrm{R}}-\frac{\Delta \mathrm{H}^{\ddagger}}{\mathrm{RT}} .
$$

\subsection{X-ray Crystallography}

The X-ray diffraction measurement was carried out on a STOE IPDS2T diffractometer (STOE \& Cie GmbH, Darmstadt, Germany) with graphite-monochromated Mo K $\alpha$ radiation. The single crystals suitable for X-ray analysis were obtained from $\mathrm{CH}_{2} \mathrm{Cl}_{2} / n$-hexane solution (at room temperature) and mounted on glass fiber, and used for data collection. Cell constants and an orientation matrix for data collection were obtained by least-square refinement of the diffraction data for $\mathbf{1 c}$ and $\mathbf{2 c}$. Diffraction data were collected in a series of $\omega$ scans in $1^{\circ}$ oscillations and integrated using the Stoe X-AREA software package (Stoe \& Cie GmbH, Darmstadt, Germany) [80]. Numerical absorption correction was applied using X-Red32 software (Stoe \& Cie GmbH, Darmstadt, Germany). The structure was solved by direct methods and subsequent difference Fourier maps and then refined on F2 by a full-matrix least-squares procedure using anisotropic displacement parameters. Atomic factors are from the International Tables for X-ray Crystallography. All non-hydrogen atoms were refined with anisotropic displacement parameters. Hydrogen atoms were placed in ideal positions and refined as riding atoms with relative isotropic displacement parameters. All refinements were performed using the X-STEP32, SHELXL-2014 and WinGX-2013.3 programs [81-85] Crystallographic data for the structural analysis was deposited with the Cambridge Crystallographic Data Centre, No. CCDC-2057874 (for 1c) and CCDC-2057873 (for 2c).

\subsection{Computational Details}

Density functional calculations were performed with the program suite Gaussian09 (Wallingford, CT, USA) [86] using the B3LYP level of theory [87-89]. The LANL2DZ basis set was chosen to describe Pt $[90,91]$ and the 6-31G(d) basis set was chosen for other atoms. The geometries of complexes were fully optimized by employing the density functional theory without imposing any symmetry constraints. To ensure the optimized geometries, frequency calculations were performed employing analytical second derivatives. $\mathrm{CH}_{2} \mathrm{Cl}_{2}$ as solvent was introduced using the conductor-like polarizable continuum model (CPCM) $[92,93]$. The calculations for the electronic absorption spectra by time-dependent DFT (TD-DFT) were performed at the same level of theory. The compositions of molecular orbitals and theoretical absorption spectra were plotted using the "Chemissian" software (Petersburg, Russia) [94].

\section{Conclusion}

We have reported synthesis, photophysical properties of $\mathbf{1} \mathbf{b}$, and kinetic investigation of its reaction with MeI [76]. In this work, we completed the trend of phosphine ligands by synthesis of 1a and 1c. The effect of phosphines on the photophysical properties of the 
cycloplatinated(II) complexes and also on the rates of oxidative addition reactions with MeI studied. These complexes show emission bands in the yellow-orange region with the same wavelength of $550 \mathrm{~nm}$. The emission bands exhibit a structured shape, which is indicative of the mixed character ${ }^{3} \mathrm{ILCT} /{ }^{3} \mathrm{MLCT}$ and emission from the Vpy cyclometalated ligand. However, 1c shows the strongest emission, while 1a shows the weakest emission, which is probably related to the electron-donating ability of the phosphine ligands, which obeys the trend $\mathrm{PPhMe}_{2}>\mathrm{PPh}_{2} \mathrm{Me}>\mathrm{PPh}_{3}$. On the other hand, the nature of phosphine ligands affects the rate of oxidative addition reactions of cycloplatinated(II) complexes with MeI. The expected rate trend of $\mathbf{1 c}>\mathbf{1 b}>\mathbf{1 a}$ was obtained, which is attributed to the electron-donating ability of the phosphine ligands $\left(\mathrm{PPhMe}_{2}>\mathrm{PPh}_{2} \mathrm{Me}>\mathrm{PPh}_{3}\right)$, being favorable for the oxidative addition reaction. In this regard, trans to cis isomerization is also observed for two cases of $\mathbf{2 a}$ (very fast) and $\mathbf{2 b}$ (slow), which is controlled by the steric hindrance induced by the phosphine. However, $2 \mathrm{c}$ as the trans isomer and kinetic product is stable and can be isolated and crystallized, which is due to the small steric hindrance of the $\mathrm{PPhMe}_{2}$ ligand.

Supplementary Materials: The following are available online at: Crystallographic and Computational data, NMR spectra. Figure S1: ${ }^{1} \mathrm{H}$ NMR spectrum of $1 \mathrm{a}$ in acetone- $d_{6}$, Figure S2: ${ }^{1} \mathrm{H}$ NMR spectrum of $1 \mathbf{c}$ in acetone- $d_{6}$, Figure S3: ${ }^{1} \mathrm{H}$ NMR spectrum of $3 \mathbf{a}$ in acetone- $d_{6}$, Figure S4: ${ }^{1} \mathrm{H}$ NMR spectrum of 2 c in acetone- $d_{6}$, Figure $S 5:{ }^{31} \mathrm{P}\left\{{ }^{1} \mathrm{H}\right\}$ NMR spectrum of $1 \mathbf{a}$ in acetone- $d_{6}$, Figure $S 6:{ }^{31} \mathrm{P}\left\{{ }^{1} \mathrm{H}\right\}$ NMR spectrum of $1 \mathbf{c}$ in acetone- $d_{6}$, Figure $57:{ }^{31} \mathrm{P}\left\{{ }^{1} \mathrm{H}\right\}$ NMR spectrum of $3 \mathbf{a}$ in acetone- $d_{6}$, Figure S8: ${ }^{31} \mathrm{P}\left\{{ }^{1} \mathrm{H}\right\}$ NMR spectrum of $\mathbf{2 c}$ in acetone- $d_{6}$, Figure S9: Optimized structures of (a) $\mathbf{1 a}$, (b) $\mathbf{1 b}$ and (c) $\mathbf{1} \mathbf{c}$ in $\mathrm{CH}_{2} \mathrm{Cl}_{2}$ solvent, Figure S10: Selected MO plots of $\mathbf{1 a}$, Figure S11: Selected MO plots of $\mathbf{1 b}$, Figure S12: Selected MO plots of 1c, Table S1: Crystal data and structure refinements for 1c and 2c, Table S2: Selected geometrical parameters for the optimized structures of 1a-c, Table S3: Composition (\%) of frontier MOs in the ground state for $1 \mathrm{a}$ in $\mathrm{CH}_{2} \mathrm{Cl}_{2}$ solvent, Table S4: Composition (\%) of frontier MOs in the ground state for $\mathbf{1 b}$ in $\mathrm{CH}_{2} \mathrm{Cl}_{2}$ solvent, Table S5: Composition (\%) of frontier MOs in the ground state for $1 \mathrm{c}$ in $\mathrm{CH}_{2} \mathrm{Cl}_{2}$ solvent.

Author Contributions: Conceptualization, H.R.S.; methodology, S.H. and R.B.A.; software, V.D., R.B.A., S.P., M.G.H. and M.R.H.; investigation, all authors; resources, H.R.S.; writing-original draft preparation, V.D., S.H., R.B.A. and S.P.; writing—review and editing, H.R.S.; visualization, H.R.S. and R.B.A.; project administration, H.R.S. All authors have read and agreed to the published version of the manuscript.

Funding: This work was supported by the Institute for Advanced Studies in Basic Sciences (IASBS) Research Council and the Iran National Science Foundation (grant no. 99002060).

Data Availability Statement: Data is contained within the article or Supplementary Materials.

Conflicts of Interest: The authors declare that they have no conflicts of interest.

Sample Availability: Samples of the compounds are available from the authors.

\section{References}

1. Saris, P.J.G.; Thompson, M.E. Gram Scale Synthesis of Benzophenanthroline and Its Blue Phosphorescent Platinum Complex. Org. Lett. 2016, 18, 3960-3963. [CrossRef] [PubMed]

2. Berenguer, J.R.; Lalinde, E.; Moreno, M.T.; Sánchez, S.; Torroba, J. Facile Metalation of Hbzq by [cis-Pt $\left.\left(\mathrm{C}_{6} \mathrm{~F}_{5}\right)_{2}(\mathrm{thf})_{2}\right]$ : A Route to a Pentafluorophenyl Benzoquinolate Solvate Complex That Easily Coordinates Terminal Alkynes. Spectroscopic and Optical Properties. Inorg. Chem. 2012, 51, 11665-11679. [CrossRef]

3. Fuertes, S.; Chueca, A.J.; Arnal, L.; Martín, A.; Giovanella, U.; Botta, C.; Sicilia, V. Heteroleptic Cycloplatinated N-Heterocyclic Carbene Complexes: A New Approach to Highly Efficient Blue-Light Emitters. Inorg. Chem. 2017, 56, 4829-4839. [CrossRef] [PubMed]

4. Fuertes, S.; Chueca, A.J.; Perálvarez, M.; Borja, P.; Torrell, M.; Carreras, J.; Sicilia, V. White Light Emission from Planar Remote Phosphor Based on NHC Cycloplatinated Complexes. ACS Appl. Mater. Interfaces 2016, 8, 16160-16169. [CrossRef]

5. Micksch, M.; Tenne, M.; Strassner, T. C $\wedge$ N-Cyclometalated Platinum(II) Complexes with Sterically Demanding 1,2Diarylimidazole Ligands. Organometallics 2014, 33, 3464-3473. [CrossRef]

6. Aghakhanpour, R.B.; Nabavizadeh, S.M.; Rashidi, M.; Kubicki, M. Luminescence properties of some monomeric and dimeric cycloplatinated(ii) complexes containing biphosphine ligands. Dalton Trans. 2015, 44, 15829-15842. [CrossRef] 
7. Chakraborty, A.; Yarnell, J.E.; Sommer, R.D.; Roy, S.; Castellano, F.N. Excited-State Processes of Cyclometalated Platinum(II) Charge-Transfer Dimers Bridged by Hydroxypyridines. Inorg. Chem. 2018, 57, 1298-1310. [CrossRef]

8. Moussa, J.; Loch, A.; Chamoreau, L.-M.; Degli Esposti, A.; Bandini, E.; Barbieri, A.; Amouri, H. Luminescent Cyclometalated Platinum Complexes with $\pi$-Bonded Catecholate Organometallic Ligands. Inorg. Chem. 2017, 56, 2050-2059. [CrossRef]

9. Paziresh, S.; Aghakhanpour, R.B.; Fuertes, S.; Sicilia, V.; Hosseini, F.N.; Nabavizadeh, S.M. A double rollover cycloplatinated(ii) skeleton: A versatile platform for tuning emission by chelating and non-chelating ancillary ligand systems. Dalton Trans. 2019, 48, 5713-5724. [CrossRef] [PubMed]

10. Nikahd, S.; Aghakhanpour, R.B.; Nabavizadeh, S.M.; Hosseini, F.N.; Hoseini, S.J.; Pfitzner, A.; Sangari, M.S. Luminescent mononuclear and dinuclear cycloplatinated (II) complexes comprising azide and phosphine ancillary ligands. Appl. Organomet. Chem. 2019, 33, 5197. [CrossRef]

11. Aghakhanpour, R.B.; Nabavizadeh, S.M.; Rashidi, M. Newly designed luminescent di- and tetra-nuclear double rollover cycloplatinated(II) complexes. J. Organomet. Chem. 2016, 819, 216-227. [CrossRef]

12. Chi, Y.; Chou, P.-T. Transition-metal phosphors with cyclometalating ligands: Fundamentals and applications. Chem. Soc. Rev. 2010, 39, 638-655. [CrossRef] [PubMed]

13. Wenger, O.S. Vapochromism in Organometallic and Coordination Complexes: Chemical Sensors for Volatile Organic Compounds. Chem. Rev. 2013, 113, 3686-3733. [CrossRef] [PubMed]

14. Berenguer, J.R.; Lalinde, E.; Moreno, M.T. Luminescent cyclometalated-pentafluorophenyl Pt ${ }^{\mathrm{II}}$, $\mathrm{Pt}^{\mathrm{IV}}$ and heteropolynuclear complexes. Coord. Chem. Rev. 2018, 366, 69-90. [CrossRef]

15. Shahsavari, H.R.; Paziresh, S.; Babadi Aghakhanpour, R.; Chamyani, S. Luminescent Cycloplatinated(II) Complexes: Impact of Ancillary Ligands and Second Metals. Inorg. Chem. Res. 2020, 4, 225-249.

16. Rausch, A.F.; Homeier, H.H.H.; Yersin, H. ChemInform Abstract: Organometallic Pt(II) and Ir(III) Triplet Emitters for OLED Applications and the Role of Spin-Orbit Coupling: A Study Based on High-Resolution Optical Spectroscopy. Chemin- 2010, 42, 193-235. [CrossRef]

17. Murphy, L.; Gareth Williams, J.A. Luminescent Platinum Compounds: From Molecules to OLEDs In Molecular organometallic materials for optics; Springer: Berlin/Heidelberg, Germany, 2010; pp. 75-111.

18. Yersin, H. Highly Efficient OLEDs with Phosphorescent Materials; WILEY-VCH Verlag GmbH \& Co. KGaA: Weinheim, Germany, 2008.

19. Pashaei, B.; Shahroosvand, H.; Graetzel, M.; Nazeeruddin, M.K. Influence of Ancillary Ligands in Dye-Sensitized Solar Cells. Chem. Rev. 2016, 116, 9485-9564. [CrossRef]

20. Yam, V.W.-W.; Tang, R.P.-L.; Wong, K.M.-C.; Lu, X.-X.; Cheung, K.-K.; Zhu, N. Syntheses, Electronic Absorption, Emission, and Ion-Binding Studies of Platinum(II) $\mathrm{C}^{\wedge} \mathrm{N}^{\wedge} \mathrm{C}$ and Terpyridyl Complexes Containing Crown Ether Pendants. Chem.-A Eur. J. 2002, 8, 4066-4076. [CrossRef]

21. Lanoë, P.-H.; Le Bozec, H.; Williams, J.A.G.; Fillaut, J.-L.; Guerchais, V. Cyclometallated platinum(ii) complexes containing pyridyl-acetylide ligands: The selective influence of lead binding on luminescence. Dalton Trans. 2010, 39, 707-710. [CrossRef]

22. Shavaleev, N.M.; Adams, H.; Best, J.; Edge, R.; Navaratnam, S.; Weinstein, J.A. Deep-Red Luminescence and Efficient Singlet Oxygen Generation by Cyclometalated Platinum(II) Complexes with 8-Hydroxyquinolines and Quinoline-8-thiol. Inorg. Chem. 2006, 45, 9410-9415. [CrossRef]

23. Liu, J.; Leung, C.-H.; Chow, A.L.-F.; Sun, R.W.-Y.; Yan, S.-C.; Che, C.-M. Cyclometalated platinum(ii) complexes as topoisomerase II $\alpha$ poisons. Chem. Commun. 2011, 47, 719-721. [CrossRef] [PubMed]

24. Bossi, A.; Rausch, A.F.; Leitl, M.J.; Czerwieniec, R.; Whited, M.T.; Djurovich, P.I.; Yersin, H.; Thompson, M.E. Photophysical Properties of Cyclometalated Pt(II) Complexes: Counterintuitive Blue Shift in Emission with an Expanded Ligand $\pi$ System. Inorg. Chem. 2013, 52, 12403-12415. [CrossRef] [PubMed]

25. Niedermair, F.; Waich, K.; Kappaun, S.; Mayr, T.; Trimmel, G.; Mereiter, K.; Slugovc, C. Heteroleptic K²(N,C2)-2-phenylpyridine platinum complexes: The use of bis(pyrazolyl)borates as ancillary ligands. Inorg. Chim. Acta 2007, 360, 2767-2777. [CrossRef]

26. Berenguer, J.R.; Díez, Á.; Lalinde, E.; Moreno, M.T.; Ruiz, S.; Sánchez, S. Luminescent Cycloplatinated Complexes Containing Poly(pyrazolyl)-borate and -methane Ligands. Organometallics 2011, 30, 5776-5792. [CrossRef]

27. DePriest, J.C.; Zheng, G.Y.; Woods, C.H.; Rillema, D.; Mikirova, N.; Zandler, M.E. Structure, physical and photophysical properties of platinum(II) complexes containing 7,8-benzoquinoline and various bis(diphenylphosphine) ligands. Inorg. Chim. Acta 1997, 264, 287-296. [CrossRef]

28. Godbert, N.; Pugliese, T.; Aiello, I.; Bellusci, A.; Crispini, A.; Ghedini, M. Efficient, Ultrafast, Microwave-Assisted Syntheses of Cycloplatinated Complexes. Eur. J. Inorg. Chem. 2007, 2007, 5105-5111. [CrossRef]

29. Díez, Á.; Forniés, J.; Larraz, C.; Lalinde, E.; López, J.A.; Martín, A.; Moreno, M.T.; Sicilia, V. Structural and Luminescence Studies on $\pi \cdots \pi$ and Pt $\cdots$ Pt Interactions in Mixed Chloro-Isocyanide Cyclometalated Platinum(II) Complexes. Inorg. Chem. 2010, 49, 3239-3251. [CrossRef] [PubMed]

30. Shahsavari, H.R.; Aghakhanpour, R.B.; Babaghasabha, M.; Haghighi, M.G.; Nabavizadeh, S.M.; Notash, B. Photophysical properties of a series of cycloplatinated( ii ) complexes featuring allyldiphenylphosphane. New J. Chem. 2017, 41, 3798-3810. [CrossRef]

31. Shahsavari, H.R.; Aghakhanpour, R.B.; Hossein-Abadi, M.; Haghighi, M.G.; Notash, B.; Fereidoonnezhad, M. A new approach to the effects of isocyanide (CN-R) ligands on the luminescence properties of cycloplatinated( ii ) complexes. New J. Chem. 2017, 41, 15347-15356. [CrossRef] 
32. Paziresh, S.; Aghakhanpour, R.B.; Rashidi, M.; Nabavizadeh, S.M. Simple tuning of the luminescence properties of the double rollover cycloplatinated(ii) structure by halide ligands. New J. Chem. 2017, 42, 1337-1346. [CrossRef]

33. Díez, A.; Forniés, J.; Fuertes, S.; Lalinde, E.; Larraz, C.; López, J.A.; Martín, A.; Moreno, M.T.; Sicilia, V. Synthesis and Luminescence of Cyclometalated Compounds with Nitrile and Isocyanide Ligands. Organometallics 2009, 28, 1705-1718. [CrossRef]

34. Ezquerro, C.; Sepúlveda, A.E.; Grau-Atienza, A.; Serrano, E.; Lalinde, L.; Berenguer, J.R.; Garcia-Martinez, J. Organometallic phosphors as building blocks in sol-gel chemistry: Luminescent organometallo-silica materials. J. Mater. Chem. C 2017, 5, 9721-9732. [CrossRef]

35. Díez, Á.; Lalinde, E.; Moreno, M.T.; Ruiz, S. Structural and Photophysical Study on Alkynyl Cyclometalated Pt2Pb2 and Pt2Pb Clusters. Organometallics 2016, 35, 1735-1746. [CrossRef]

36. Forniés, J.; Giménez, N.; Ibáñez, S.; Lalinde, E.; Martín, A.; Moreno, M.T. An Extended Chain and Trinuclear Complexes Based on $\mathrm{Pt}(\mathrm{II})-\mathrm{M}(\mathrm{M}=\mathrm{Tl}(\mathrm{I}), \mathrm{Pb}(\mathrm{II}))$ Bonds: Contrasting Photophysical Behavior. Inorg. Chem. 2015, 54, 4351-4363. [CrossRef] [PubMed]

37. Fard, M.A.; Puddephatt, R.J. Oxidative addition of halogens to a Cycloneophylplatinum(II) complex and evidence for C-H bond activation at Platinum(IV). J. Organomet. Chem. 2020, 910, 121139. [CrossRef]

38. Behnia, A.; Fard, M.A.; Puddephatt, R.J. Stereochemistry of oxidative addition of methyl iodide and hydrogen peroxide to organoplatinum(II) complexes having an appended phenol group and the supramolecular chemistry of the platinum(IV) products. J. Organomet. Chem. 2019, 902, 120962. [CrossRef]

39. Sicilia, V.; Baya, M.; Borja, P.; Martín, A. Oxidation of Half-Lantern Pt $\mathrm{t}_{2}$ (II,II) Compounds by Halocarbons. Evidence of Dioxygen Insertion into a $\mathrm{Pt}(\mathrm{III})-\mathrm{CH}_{3}$ Bond. Inorg. Chem. 2015, 54, 7316-7324. [CrossRef]

40. Nabavizadeh, S.M.; Tabei, E.S.; Hosseini, F.N.; Keshavarz, N.; Jamali, S.; Rashidi, M. Diorganoplatinum(II) complexes with chelating PN ligand 2-(diphenylphosphinoamino)pyridine; synthesis and kinetics of the reaction with MeI. New J. Chem. 2010, 34, 495-499. [CrossRef]

41. Nabavizadeh, S.M.; Shahsavari, H.R.; Sepehrpour, H.; Hosseini, F.N.; Jamali, S.; Rashidi, M. Oxidative addition reaction of diarylplatinum(II) complexes with MeI in ionic liquid media: A kinetic study. Dalton Trans. 2010, 39, 7800-7805. [CrossRef]

42. Nabavizadeh, S.M.; Hoseini, S.J.; Momeni, B.Z.; Shahabadi, N.; Rashidi, M.; Pakiari, A.H.; Eskandari, K. Oxidative addition of n-alkyl halides to diimine-dialkylplatinum(ii) complexes: A closer look at the kinetic behaviors. Dalton Trans. 2008, $2414-2421$. [CrossRef]

43. Ghedini, M.; Pucci, D.; Crispini, A.; Barberio, G. Oxidative Addition to Cyclometalated Azobenzene Platinum(II) Complexes: A Route to Octahedral Liquid Crystalline Materials. Organometallics 1999, 18, 2116-2124. [CrossRef]

44. Crespo, M.; Martínez, M.; Nabavizadeh, S.M.; Rashidi, M. Kinetico-mechanistic studies on CX (X=H, F, Cl, Br, I) bond activation reactions on organoplatinum(II) complexes. Coord. Chem. Rev. 2014, 279, 115-140. [CrossRef]

45. Behnia, A.; Fard, M.A.; Blacquiere, J.M.; Puddephatt, R.J. Cycloneophylpalladium(IV) Complexes: Formation by Oxidative Addition and Selectivity of Their Reductive Elimination Reactions. Organometallics 2020, 39, 4037-4050. [CrossRef]

46. Rashidi, M.; Nabavizadeh, M.; Hakimelahi, R.; Jamali, S. Kinetics and mechanism of cleavage of the oxygen-oxygen bond in hydrogen peroxide and dibenzoyl peroxide by arylplatinum(ii) complexes. J. Chem. Soc. Dalton Trans. 2001, 3430-3434. [CrossRef]

47. Anderson, C.M.; Crespo, M.; Jennings, M.C.; Lough, A.J.; Ferguson, G.; Puddephatt, R.J. Competition between intramolecular oxidative addition and ortho metalation in organoplatinum(II) compounds: Activation of aryl-halogen bonds. Organometallics 1991, 10, 2672-2679. [CrossRef]

48. Crabtree, R.H. The Organometallic Chemistry of the Transition Metals, 6th ed.; John Wiley \& Sons, Inc.: Hoboken, NJ, USA, 2014.

49. Hartwig, J.F. Organotransition Metal Chemistry: From Bonding to Catalysis; University Science Books: Sausalito, CA, USA, 2010.

50. Canty, A.J. Organopalladium and platinum chemistry in oxidising milieu as models for organic synthesis involving the higher oxidation states of palladium. Dalton Trans. 2009, 10409-10417. [CrossRef] [PubMed]

51. Rendina, L.M.; Puddephatt, R.J. Oxidative Addition Reactions of Organoplatinum(II) Complexes with Nitrogen-Donor Ligands. Chem. Rev. 1997, 97, 1735-1754. [CrossRef]

52. Cross, W.B.; Hope, E.G.; Lin, Y.-H.; Macgregor, S.A.; Singh, K.; Solan, G.A.; Yahya, N. N,N-Chelate-control on the regioselectivity in acetate-assisted C-H activation. Chem. Commun. 2013, 49, 1918-1920. [CrossRef]

53. Boutadla, Y.; Davies, D.L.; MacGregor, S.A.; Bahamonde, A.I.P. Mechanisms of C-H bond activation: Rich synergy between computation and experiment. Dalton Trans. 2009, 5820-5831. [CrossRef]

54. Pérez-Rodríguez, M.; Braga, A.A.C.; Garcia-Melchor, M.; Pérez-Temprano, M.H.; Casares, J.A.; Ujaque, G.; De Lera, A.R.; Álvarez, R.; Maseras, F.; Espinet, P.C.-C. Reductive Elimination in Palladium Complexes, and the Role of Coupling Additives. A DFT Study Supported by Experiment. J. Am. Chem. Soc. 2009, 131, 3650-3657. [CrossRef]

55. Roiban, G.-D.; Serrano, E.; Soler, T.; Aullón, G.; Grosu, I.; Cativiela, C.; Martínez, M.; Urriolabeitia, E.P.; Roiban, D.; Martínez, M. Regioselective Orthopalladation of (Z)-2-Aryl-4-Arylidene-5(4H)-Oxazolones: Scope, Kinetico-Mechanistic, and Density Functional Theory Studies of the C-H Bond Activation. Inorg. Chem. 2011, 50, 8132-8143. [CrossRef] [PubMed]

56. Nabavizadeh, S.M.; Amini, H.; Jame, F.; Khosraviolya, S.; Shahsavari, H.R.; Hosseini, F.N.; Rashidi, M. Oxidative addition of MeI to some cyclometalated organoplatinum(II) complexes: Kinetics and mechanism. J. Organomet. Chem. 2012, 698, 53-61. [CrossRef]

57. Aghakhanpour, R.B.; Nabavizadeh, S.M.; Mohammadi, L.; Jahromi, S.A.; Rashidi, M. A kinetic approach to carbon-iodide bond activation by rollover cycloplatinated(II) complexes containing monodentate phosphine ligands. J. Organomet. Chem. 2015, 781, 47-52. [CrossRef] 
58. Maidich, L.; Zucca, A.; Clarkson, G.J.; Rourke, J.P. Oxidative Addition of MeI to a Rollover Complex of Platinum(II): Isolation of the Kinetic Product. Organometallics 2013, 32, 3371-3375. [CrossRef]

59. Zucca, A.; Maidich, L.; Canu, L.; Petretto, G.L.; Stoccoro, S.; Cinellu, M.A.; Clarkson, G.J.; Rourke, J.P. Rollover-Assisted C(sp2)-C(sp3) Bond Formation. Chem.-A Eur. J. 2014, 20, 5501-5510. [CrossRef] [PubMed]

60. Aghakhanpour, R.B.; Rashidi, M.; Hosseini, F.N.; Raoof, F.; Nabavizadeh, S.M. Oxidation of a rollover cycloplatinated(II) dimer by MeI: A kinetic study. RSC Adv. 2015, 5, 66534-66542. [CrossRef]

61. Raoof, F.; Boostanizadeh, M.; Esmaeilbeig, A.R.; Nabavizadeh, S.M.; Aghakhanpour, R.B.; Ghiassi, K.B.; Olmstead, M.M.; Balch, A.L. Reactivity comparison of five-and six-membered cyclometalated platinum(II) complexes in oxidative addition reactions. RSC Adv. 2015, 5, 85111-85121. [CrossRef]

62. Jamali, S.; Nabavizadeh, S.M.; Rashidi, M. Binuclear Cyclometalated Organoplatinum Complexes Containing 1,1'Bis(diphenylphosphino)ferrocene as Spacer Ligand: Kinetics and Mechanism of MeI Oxidative Addition. Inorg. Chem. 2008, 47, 5441-5452. [CrossRef]

63. Chen, L.; Poë, A.J. Associative reactions of metal carbonyl clusters: Systematic kinetic studies of some ruthenium and other clusters. Coord. Chem. Rev. 1995, 143, 265-295. [CrossRef]

64. Hu, J.; Nikravesh, M.; Shahsavari, H.R.; Aghakhanpour, R.B.; Rheingold, A.L.; Alshami, M.; Sakamaki, Y.; Beyzavi, H. A CN Cycloplatinated(II) Fluoride Complex: Photophysical Studies and Csp3-F Bond Formation. Inorg. Chem. 2020, 59, 16319-16327. [CrossRef]

65. Nazari, M.; Shahsavari, H.R. Strong red emissions induced by Pt-Pt interactions in binuclear cycloplatinated(II) complexes containing bridging diphosphines. Appl. Organomet. Chem. 2019, 33, 5020. [CrossRef]

66. Shahsavari, H.R.; Giménez, N.; Lalinde, E.; Moreno, M.T.; Fereidoonnezhad, M.; Aghakhanpour, R.B.; Khatami, M.; Kalantari, F.; Jamshidi, Z.; Mohammadpour, M. Heterobimetallic PtII -AuI Complexes Comprising Unsymmetrical 1,1Bis(diphenylphosphanyl)methane Bridges: Synthesis, Photophysical, and Cytotoxic Studies. Eur. J. Inorg. Chem. 2019, 2019, 1360-1373. [CrossRef]

67. Shahsavari, H.R.; Aghakhanpour, R.B.; Nikravesh, M.; Ozdemir, J.; Haghighi, M.G.; Notash, B.; Beyzavi, M.H. Highly Emissive Cycloplatinated(II) Complexes Obtained by the Chloride Abstraction from the Complex $\left[\mathrm{Pt}(\mathrm{ppy})\left(\mathrm{PPh}_{3}\right)(\mathrm{Cl})\right]$ : Employing Various Silver Salts. Organometallics 2018, 37, 2890-2900. [CrossRef]

68. Fereidoonnezhad, M.; Kaboudin, B.; Mirzaee, T.; Aghakhanpour, R.B.; Haghighi, M.G.; Faghih, Z.; Faghih, Z.; Ahmadipour, Z.; Notash, B.; Shahsavari, H.R. Cyclometalated Platinum(II) Complexes Bearing Bidentate O,O'-Di(alkyl)dithiophosphate Ligands: Photoluminescence and Cytotoxic Properties. Organometallics 2017, 36, 1707-1717. [CrossRef]

69. Jamshidi, M.; Babaghasabha, M.; Shahsavari, H.R.; Nabavizadeh, S.M. The influence of thiolate ligands on the luminescence properties of cycloplatinated(ii) complexes. Dalton Trans. 2017, 46, 15919-15927. [CrossRef] [PubMed]

70. Shahsavari, H.R.; Aghakhanpour, R.B.; Biglari, A.; Niazi, M.; Mastrorilli, P.; Todisco, S.; Gallo, V.; Lalinde, E.; Moreno, M.T.; Giménez, N.; et al. C(sp2)-C(sp2) Reductive Elimination from a Diarylplatinum(II) Complex Induced by a S-S Bond Oxidative Addition at Room Temperature. Organometallics 2020, 39, 417-424. [CrossRef]

71. Chamyani, S.; Shahsavari, H.R.; Abedanzadeh, S.; Haghighi, M.G.; Shabani, S.; Notash, B. Carbon-iodide bond activation by cyclometalated Pt (II) complexes bearing tricyclohexylphosphine ligand: A comparative kinetic study and theoretical elucidation. Appl. Organomet. Chem. 2019, 33, e4674. [CrossRef]

72. Shahsavari, H.R.; Aghakhanpour, R.B.; Hossein-Abadi, M.; Kia, R.; Raithby, P.R. Stable trans isomer as the kinetic and theromodynamic product for the oxidative addition of MeI to cycloplatinated(II) complexes comprising isocyanide ligands. Appl. Organomet. Chem. 2018, 32, e4216. [CrossRef]

73. Shahsavari, H.R.; Aghakhanpour, R.B.; Fereidoonnezhad, M. An in-depth investigation on the C-I bond activation by rollover cycloplatinated(ii) complexes bearing monodentate phosphane ligands: Kinetic and kinetic isotope effect. New J. Chem. 2018, 42, 2564-2573. [CrossRef]

74. Shahsavari, H.R.; Aghakhanpour, R.B.; Babaghasabha, M.; Haghighi, M.G.; Nabavizadeh, S.M.; Notash, B. Combined KineticoMechanistic and Theoretical Elucidation of the Oxidative Addition of Iodomethane to Cycloplatinated(II) Complexes: Controlling the Rate of trans/cis Isomerization. Eur. J. Inorg. Chem. 2017, 2017, 2682-2690. [CrossRef]

75. Zucca, A.; Maidich, L.; Carta, V.; Petretto, G.L.; Stoccoro, S.; Cinellu, M.A.; Pilo, M.I.; Clarkson, G.J. Cyclometalated Complexes of Platinum(II) with 2-Vinylpyridine. Eur. J. Inorg. Chem. 2014, 2014, 2278-2287. [CrossRef]

76. Niazi, M.; Shahsavari, H.R. Cycloplatinated(II) complex bearing 2-vinylpyridine and monodentate phosphine ligands: Optical properties and kinetic study. J. Organomet. Chem. 2016, 803, 82-91. [CrossRef]

77. Niazi, M.; Shahsavari, H.R. Organoplatinum(II) Complexes Featuring the 2-Vinylpyridine Ligand. ChemistrySelect 2016, 1, 1780-1783. [CrossRef]

78. Facchetti, G.; Cesarotti, E.; Pellizzoni, M.; Zerla, D.; Rimoldi, I. “In situ” Activation of Racemic RuII Complexes: Separation of trans and cis Species and Their Application in Asymmetric Reduction. Eur. J. Inorg. Chem. 2012, 2012, 4365-4370. [CrossRef]

79. Wilkins, R.G. Kinetics and Mechanism of Reactions of Transition Metal Complexes. In Kinetics and Mechanism of Reactions of Transition Metal Complexes; Wiley: Weinheim, Germany, 1991.

80. Stoe \& Cie. X-AREA: Program for the Acquisition and Analysis of Data, version 1.30; Stoe \& Cie GmbH: Darmstadt, Germany, 2005.

81. Farrugia, L.J. WinGX and ORTEP for Windows: An update. J. Appl. Cryst. 2012, 45, 849-854. [CrossRef] 
82. Coppens, P.; Leiserowitz, L.; Rabinovich, D. Calculation of absorption corrections for camera and diffractometer data. Acta Crystallogr. 1965, 18, 1035-1038. [CrossRef]

83. Farrugia, L.J. WinGX suite for small-molecule single-crystal crystallography. J. Appl. Cryst. 1999, 32, 837-838. [CrossRef]

84. Macrae, C.F.; Edgington, P.R.; McCabe, P.; Pidcock, E.; Shields, G.P.; Taylor, R.D.; Towler, M.; Van De Streek, J. Mercury: Visualization and analysis of crystal structures. J. Appl. Crystallogr. 2006, 39, 453-457. [CrossRef]

85. Sheldrick, G.M. A short history of SHELX. Acta Crystallogr. Sect. A 2008, 64, 112-122. [CrossRef]

86. Frisch, M.J.; Trucks, G.W.; Schlegel, H.B.; Scuseria, G.E.; Robb, M.A.; Cheeseman, J.R.; Scalmani, G.; Barone, V.; Mennucci, B.; Petersson, G.A.; et al. Gaussian 09; Revision A.02. Inc.: Wallingford, CT, USA, 2016. Available online: https://gaussian.com/g0 9citation/ (accessed on 20 January 2021).

87. Becke, A.D. Density-functional thermochemistry. III. The role of exact exchange. J. Chem. Phys. 1993, 98, 5648-5652. [CrossRef]

88. Miehlich, B.; Savin, A.; Stoll, H.; Preuss, H. Results obtained with the correlation energy density functionals of becke and Lee, Yang and Parr. Chem. Phys. Lett. 1989, 157, 200-206. [CrossRef]

89. Lee, C.; Yang, W.; Parr, R.G. Development of the Colle-Salvetti correlation-energy formula into a functional of the electron density. Phys. Rev. B 1988, 37, 785-789. [CrossRef] [PubMed]

90. Wadt, W.R.; Hay, P.J. Ab initio effective core potentials for molecular calculations. Potentials for main group elements Na to Bi. J. Chem. Phys. 1985, 82, 284-298. [CrossRef]

91. Roy, L.E.; Hay, P.J.; Martin, R.L. Revised Basis Sets for the LANL Effective Core Potentials. J. Chem. Theory Comput. 2008, 4, 1029-1031. [CrossRef]

92. Cossi, M.; Scalmani, G.; Rega, N.; Barone, V. New developments in the polarizable continuum model for quantum mechanical and classical calculations on molecules in solution. J. Chem. Phys. 2002, 117, 43-54. [CrossRef]

93. Barone, V.; Cossi, M.; Tomasi, J. A new definition of cavities for the computation of solvation free energies by the polarizable continuum model. J. Chem. Phys. 1997, 107, 3210-3221. [CrossRef]

94. Skripnikov, L. Chemissian: Software to Analyze Spectra, Build Density Maps and Molecular Orbitals. Version 2016, 4. Available online: https: / / www.chemissian.com/download (accessed on 20 January 2021). 